\title{
THE EUROPEAN UNION AND CRISIS MANAGEMENT: WILL THE LISBON TREATY MAKE THE EU MORE EFFECTIVE?
}

\author{
Steven Blockmans and Ramses A. Wessel ${ }^{1}$ \\ Paper presented at the international conference The European Union and Global Emergencies, \\ Durham European Law Institute, 8-9 May 2009 - work in progress
}

\begin{abstract}
The European Union's security and defence policy was invented ten years ago and has been operational for more than five years. During this period the EU has launched over twenty ESDP missions allowing the organisation to be engaged in international crisis management in various ways. The coming years will reveal whether the European Union is able to meet its ambitions. Arguably, the new Treaty of Lisbon introduces quite a few institutional changes to the current treaty regime of foreign affairs and security policy, but it is highly unlikely that these innovations will significantly improve the decision-making and leadership on issues of ESDP and, consequently, the effectiveness of the Union as an international crisis manager.
\end{abstract}

"[M]ore than 20 civilian and military operations, are or have been deployed on almost every continent, from Europe to Asia, from the Middle East to Africa. Thousands of European men and women are engaged in these operations, ranging from military to police, from border guards to monitors, from judges to prosecutors, a wide range of people doing good for the stability of the world. This is the European way of doing things: a comprehensive approach to crisis prevention and crisis management; a large and diversified tool box; a rapid response capability; playing our role as a global actor. Obviously, if the Lisbon Treaty were to be ratified, and I hope it will be, we would be even more effective."

Javier Solana, 18 February $2009^{2}$

1 S. Blockmans is Senior Research Fellow in EU Law at the T.M.C. Asser Institute, The Hague; R.A. Wessel is Professor of the Law of the European Union and other International Organizations, Centre for European Studies, University of Twente, The Netherlands (see for other relevant publications: www.mb.utwente.nl/legs/staff/wessel/publications). Both authors are board members of the new Centre for the Law of EU External Relations (CLEER) in The Hague (www.cleer.eu).

2 Address by the EU Representative for the CFSP, Javier Solana, to the European Parliament, Brussels, 18 February 2009, Doc. S045/09. 
Most informed observers recognise that the word 'crisis' is over-used when it comes to the European Union. ${ }^{3}$ The story of European integration has been most frequently described in terms of a perpetual sense of division, diplomatic wrangling and failure to meet targets and deadlines. Similarly, the perceived failure of the EU to punch its weight in both global and regional geopolitics is often criticised. Both as a 'soft power' and in its approach to harder security issues, the EU is often perceived by others as unstable, weak and ineffective. ${ }^{4}$ While it is an undeniable fact that, in little more than fifty years, war between the European Member States themselves has become unthinkable, the Union's record in terms of 'crisis management' abroad, especially in wars waged in its neighbourhood, is indeed mixed at best. The famous and ill-fated declaration of Luxembourg's former minister of foreign affairs Jacques Poos that Yugoslavia's violent implosion in 1991 heralded "the hour of Europe" may have been morally true, it certainly was not politically. Neither the wars on the territory of the former Yugoslavia nor the recent conflicts in the EU's neighbourhood (the Caucasus, the Middle East) have posed an existential threat to (parts of) the Union. Is it perhaps for this reason that the Member States have almost always failed the test of unity in the EU's efforts to resolve conflicts on its borders?

This paper assesses the Lisbon Treaty's amendments in the field of the Union's foreign, security and defence policy and questions whether they sufficiently equip the European Union with the legal and institutional framework to face the maturity test in crisis management which it is currently facing. To this end, some legal as well as semantic clarifications will be made (section 2) before a critical overview is given of the legal-institutional build-up and conduct of EU missions in the first five years since the European Security and Defence Policy (ESDP) was declared operational (section 3). On the basis of an analysis of the operational shortcomings ${ }^{5}$ which the EU faces in the

3 See, e.g., M. Leonard, Why Europe Will Run the $21^{\text {st }}$ Century (London and New York, Fourth Estate 2005), at 4.

4 N. Chaban, O. Elgström and M. Holland, “The European Union as Others See It”, 11 EFA Rev. (2006), 245-262. For more recent figures and clues, see the ongoing survey coordinated by S. Lucarelli, 'Research Report: the External Image of the European Union', GARNET Working Paper No. 17 (Dublin, GARNET 2007). A first set of data drawn from the survey as published by L. Fioramonti and S. Lucarelli, 'How Do the Others See Us? European Political Identity and the External Image of the EU', in F. Cerutti and S. Lucarelli (eds.), The Search for a European Identity: Values, Policies and Legitimacy of the European Union (London/New York, 2008), 193210.

Measuring the success, failure and effectiveness of policy making and concrete actions targeted at creating stability and security on the European continent and farther afield is fraught with difficulties. It is near to impossible to determine to what extent single efforts and approaches have led to positive or negative results at a more general level. Nevertheless, a number of activities and approaches may be ascribed a positive (or negative) influence on developments that have the potential to undermine the stability and security of a situation. It is on the basis of such general perceptions that general conclusions can be drawn. 
formulation of a solid strategy, the translation of that vision into policy, and the implementation thereof by way of the capabilities created (section 4), the amendments introduced by the Lisbon Treaty will be assessed (section 5) with an aim to answer the question whether the new 'Common' Security and Defence Policy (CSDP) will prepare the Union for bigger, more complex and longer term operations in more dangerous theatres around the world (section 6).

\section{SOME PRELIMINARY CLARIFICATIONS: THE LISBON TREATY AND CRISIS MANAGEMENT}

\subsection{The Lisbon Treaty}

On 18 December 2007 the representatives of the 27 Member States of the European Union signed the Treaty of Lisbon amending the Treaty on European Union and the Treaty establishing the European Community. ${ }^{6}$ The Treaty of Lisbon has seven Articles only. Articles 1 and 2 list all amendments to - respectively - the current Treaty on European Union (TEU) and the Treaty establishing the European Community (TEC); Articles 3-7 contain some final provisions on, inter alia, the duration of the treaty, the ratification procedure and the renumbering of articles. Thus, in contrast to the 2004 Treaty establishing a Constitution for Europe - that never came into force due to a negative outcome of referenda in France and The Netherlands - the Lisbon Treaty does not intend to replace the current treaties, but rather to amend them. After the entry into force, ${ }^{7}$ we will have new, consolidated versions of both the EU Treaty and the EC Treaty (which will be renamed to Treaty on the Function of the European Union - TFEU).

The reason for the conclusion of the Lisbon Treaty can be found in its preamble: "to complete the process started by the Treaty of Amsterdam and by the Treaty of Nice with a view to enhancing the efficiency and democratic legitimacy of the Union and to improving the coherence of its action.” The preamble of the Lisbon Treaty thus makes clear that strengthening the Union's role in the world is one of the reasons for its conclusion. Indeed, coherence of the EU's external action is currently seriously hampered by the institutional structure of the Union, in which external competences and procedures in all three pillars (the European Communities, the Common Foreign and Security Policy, and the Police and Judicial Cooperation in Criminal Matters) are artificially kept apart. In that respect the dissolution of the pillar structure and the merger of the European Union

6 Throughout this paper, references to provisions of the Lisbon Treaty have been based on the consolidated versions of the TEU and the TFEU, as published in OJ 2008 C 115/1.

On 12 June 2008 the Lisbon Treaty was rejected in an Irish referendum. A new referendum is foreseen later this year and it remains difficult to speculate on the outcome. See for the possible future scenarios regarding the CFSP/ESDP provisions in the Lisbon Treaty: R. Whitman and A. Juncos, 'The Lisbon Treaty and the Foreign, Security and Defence Policy: Reforms, Implementation and the Consequences of (non-)Ratification', 14 EFA Rev (2009), 25-49. 
and the European Community potentially adds to the coherence of the Union's external action.

The Lisbon Treaty not only integrates the European Community ${ }^{8}$ into the European Union, but the new Treaty on European Union also explicitly provides that "The Union shall have legal personality" (Art. 7), thus making an end to the academic discussion on the legal status of the Union. ${ }^{9}$ That there is still some uneasiness on the part of some Member States, is reflected in Declaration No. 24, attached to the Lisbon Final Act: "The Conference confirms that the fact that the European Union has a legal personality will not in any way authorise the Union to legislate or to act beyond the competences conferred upon it by the Member States in the Treaties." Like many Declarations, this one also states the obvious. After all, the principle of attributed (or conferred) powers forms a starting point in international institutional law and is even explicitly referred to in the new TEU, this time with no exception for the Common Foreign and Security Policy (CFSP): "Under the principle of conferral, the Union shall act only within the limits of the competences conferred upon it by the Member States in the Treaties to attain the objectives set out therein. Competences not conferred upon the Union in the Treaties remain with the Member States” (Art. 5). ${ }^{10}$ Similar careful considerations can be found in Declarations no. 13 and 14, which underline that the new changes "do not affect the responsibilities of the Member States, as they currently exist [...]" and do not "prejudice the specific character of the security and defence policy of the Member States”. It has been argued that, taken together - and apart from their declaratory nature, these Declarations may nevertheless prevent a 'communitarisation' of the Union's foreign, security and defence policy. ${ }^{11}$

The new TEU contains all institutional provisions, whereas all policy areas (including the current EU third pillar on Police and Judicial Cooperation in Criminal matters) will be part of the reformed EC Treaty, the new TFEU. It is therefore striking that both the CFSP and the new Common Security and Defence Policy (CSDP) will remain part of the TEU. Indeed, the current 'second pillar' will be the only policy area that will continue to have a separate status in EU law and even within Title $\mathrm{V}$ on the 'General Provisions on the Union's External Action' there is a separate section on 'Special Provisions on the Common Foreign and Security Policy'. It has been argued that

$8 \quad$ The European Atomic Energy Community (Euratom) will not be part of the new structure and will continue to be a separate international organization. See also Protocol 2 annexed to the Treaties.

$9 \quad$ See on this discussion the many references in R.A. Wessel, 'The International Legal Status of the European Union' (1997) 2 EFA Rev 109; as well as 'Revisiting the International Legal Status of the EU' (2000) 5 EFA Rev 507.

10 On the basis of Art. 5 TEU the principles of proportionality and subsidiarity also apply to all Union policy areas, although the Protocol on the Application of the Principles of Subsidiarity and Proportionality seems to focus on 'legislative acts' only and these acts cannot be used for CFSP matters.

11 C. Kaddous, 'Role and Position of the High Representative of the Union for Foreign Affairs and Security Policy under the Lisbon Treaty', in S. Griller and J. Ziller (Eds.), The Lisbon Treaty: Constitutionalism without a Constitutional Treaty? (Vienna, Springer 2008), 205-221, at 206. 
the second pillar de facto remains in place. ${ }^{12}$ The reasons for this continued separation could already be found in the mandate for the Lisbon Intergovernmental Conference (IGC), in which Member States could not agree on a transfer of the CFSP provisions from the TEU to the TFEU. ${ }^{13}$ From a legal institutional point of view this does not make too much sense. After all, with the end of the separation between Union law and Community law possible fears of a further 'communitarisation' of CFSP are unfounded and even within the new TFEU specific provisions (including the role of the institutions, voting rules and available legal instruments) are laid down for different policy areas.

\subsection{Semantic clarifications}

Another preliminary note relates to the term 'crisis management'. In the international context, the word 'crisis' is widely understood as an acute situation in which armed force is (likely to be) used. The much broader 'conflict' is intended to denote every national or international situation where there is a threat or breach to priority values, interests and goals. The concept of 'conflict prevention' is thus to be understood as the adoption and implementation of measures that aim to impede the escalation of a non-violent dispute into a crisis. 'Crisis management' then refers to the organisation, regulation, procedural frameworks and arrangements to contain a crisis and shape its future course while resolution is sought. 'Conflict resolution' refers to efforts to impose a (partial) settlement in the case of a crisis and consolidate the cessation of violence. Actions meant to address the root causes of crises which have been resolved are dubbed 'post-conflict reconstruction and rehabilitation measures' or, perhaps again confusingly, 'peace building'. 14

While these narrow definitions are in tune with the firm terminological distinctions employed in Article 17(2) of the current TEU and Article 43(1) of the new TEU, the dividing lines between the different categories are in practice often blurred. For instance,

S. Kurpas, 'The Treaty of Lisbon - How Much "Constitution" is Left? - An Overview of the Main Challenges', CEPS Policy Brief 147, December 2007, at 2.

13 In the words of Solana, the separation was "important conceptually" to the United Kingdom. See House of Commons, Foreign Affairs Committee, Foreign Policy Aspects of the Lisbon Treaty (third Report of Session 2007-08, London, January 2008.

The conceptual clarifications mentioned in this section have been distilled from a wide variety of policy papers, legal documents, handbooks and academic texts. See, e.g., An Agenda for Peace, UN Doc. A/47/277-S/24111, 17 June 1992, paras. 20-59; Supplement to An Agenda for Peace, UN Doc. A/50/60-S/1995/1, 3 January 1995, paras. 23-80; Report of the Panel on United Nations Peace Operations, UN Doc. A/55/305-S/2000/809, 21 August 2000; NATO Handbook (Brussels, NATO Office of Information and Press 2001); European Council, A Secure Europe in a Better World - European Security Strategy, Brussels, 12 December 2003; the High Representative's Report on the Implementation of the European Security Strategy - Providing Security in a Changing World, doc. 17104/08 (S407/08), 11 December 2008; OSCE Handbook (Vienna, OSCE Secretariat 2007); A. Schmid, Thesaurus and Glossary of Early Warning and Conflict Prevention Terms (Rotterdam, Erasmus University 1998); and P. van Tongeren, H. van de Veen and J. Verhoeven, Searching for Peace in Europe and Eurasia: An Overview of Conflict Prevention and Peace-building Activities (Boulder, Lynne Rienner 2002). 
the strategies and actions aimed at the stabilisation of a country or a region, ${ }^{15}$ adopted in the wake of a crisis, are intended to prevent the resurgence of armed violence in both the short, medium and longer term. As such, these measures could fall within the realm of both peace building and (future) conflict prevention. The same holds true for the fuzzy concept of crisis management, as evidenced by the several guises under which the EU may act as crisis manager: as a military force to 'keep' or 'make' the peace and to fend off threats to international peace and security posed by, for example, separatist groups, terrorist organisations or pirates; and in its civilian capacity by way of a wide variety of ESDP operations: police missions, rule of law missions, civilian administration missions, civil protection missions, peace monitoring missions, support missions to EU Special Representatives, border assistance missions, and security sector reform missions. ${ }^{16}$ In the EU context, the notion of 'crisis management' thus serves as a catch-all phrase for both military and civilian ESDP operations, whether they are deployed to prevent conflict from bursting into crisis, assist in enforcing the peace, keep the peace or build the peace. The finalité in the EU's terminological inflation of 'crisis management' might well boil down to the external dimension of providing security, ${ }^{17}$ in all its cross-pillar glory. ${ }^{18}$

\section{3 'CROUCHING TIGER, HIDDEN DRAGON'}

\subsection{Paper tiger}

The need to move beyond the paper security structures which were introduced in the Treaty of Maastricht during the 1991 IGC became painfully apparent with the violent disintegration of Yugoslavia at the end of that year and with the war in Bosnia and Herzegovina (1992-1995). In the absence of its own military capabilities under the newly launched Common Foreign and Security Policy, the European Union could, however, avail itself of the Western European Union (WEU) to elaborate and implement decisions and actions of the Council which had 'defence' implications. ${ }^{19}$ The word 'defence' had to be interpreted in the broad sense, as a common defence of the territory of the European Union, similar to clauses laid down in Article 5 of the Washington Treaty (NATO) and

15

16

17

19

The term 'stabilisation' is used here as a conceptual umbrella to cover all efforts geared towards removing the determinants of conflicts and crises.

One should note that election monitoring missions do not feature among this categorisation of ESDP operations, because they are financed out of the Commission's budget.

This point is derived from a Council official during the Jean Monnet Workshop on EU External Relations, jointly organised by Maastricht University and the T.M.C. Asser Institute on 5 and 6 June 2008 at Kasteel Vaeshartelt, near Maastricht, as a precursor to the establishment of the Centre for the Law of EU External Relations (CLEER).

See infra, sections 4 and 5.

Article J.4(2) TEU. See also the document on the "Relations between the Union and the WEU", adopted by the Council of the EU on 26 October 1993 and accepted by the WEU Council of Ministers on 22 November 1993, published in Bull. EU 10-1993 and as Document 1412 of the Assembly of the WEU, 8 April 1994. 
Article $\mathrm{V}$ of the Modified Brussels Treaty (WEU), was excluded from the Treaty on European Union. The term referred to military cooperation in actions out-of-area.

Reviewing the significant changes that had taken place in the security situation in Europe after the outbreak of the Yugoslav crisis, the WEU Council of Ministers, at its 19 June 1992 meeting on the Petersberg (near Bonn), redefined its operational role so as to include the deployment of military units of WEU Member States for 'humanitarian and rescue tasks, peacekeeping tasks and tasks of combat forces in crisis management, including peacemaking' to implement conflict prevention or crisis management measures taken within the framework of the OSCE or the UN. ${ }^{20}$ While military units of the ten WEU Member States, all also EU Member States, conducted operations in the Adriatic and on the Danube, they did not do so in support of the European Union. ${ }^{21}$ The only official request of the EU in the first half of the nineties to make use of WEU capabilities concerned the support for the EU administration of the Bosnian town of Mostar (1994). Unfortunately, this operation was generally perceived a failure, especially by the parties to the conflict. ${ }^{22}$ With the crises in Albania (1997) and Kosovo (1999), the European Union was further embarrassed at how little it could contribute to the 'management' of crises at its doorstep.

Frustration at such inadequacies - and calls for change by others - led France and the United Kingdom, the EU Member States that pack the most military punch, to prod their colleagues at the European Council's December 1999 summit at Helsinki in carrying forward work on the development of the Union's own military and civilian crisis management capabilities. $^{23}$ At Helsinki the European Council underlined its determination to develop an autonomous capacity to take decisions and, where NATO as a whole was not engaged, to launch and conduct EU-led military operations in response to international crises. ${ }^{24}$ Since then, the EU has worked hard to close the infamous

20 The WEU Declaration of 19 June 1992 is reproduced in C. Hill and K. Smith, eds., European Foreign Policy: Key Documents (London, Routledge 2000), at 205-211.

21 See W. van Eekelen and S. Blockmans, 'European Crisis Management avant la lettre', in S. Blockmans, ed., The European Union and Crisis Management: Policy and Legal Aspects (The Hague, T.M.C. Asser Press 2008), 37-52, at 45.

22 Ibid., at 46-48. See also J. Monar, 'Mostar: Three Lessons for the European Union', 2 EFA Rev. (1997), 1-5.

See S. Blockmans, 'A New Crisis Manager at the Horizon - The Case of the European Union', 13 LJIL (2000), 255-263. As a result of a meeting between French President Jacques Chirac and British Prime Minister Tony Blair at Saint-Malo, a joint Franco-British declaration on European defence was issued on 4 December 1998, stating that ' $[\mathrm{t}$ ] autonomous action, backed up by credible military forces, the means to decide to use them and a readiness to do so, in order to respond to international crises.' The joint declaration is reproduced in Hill and Smith, eds., op. cit., at 243-244.

See Bull. EU 12-1999. The WEU Council facilitated this ambition by the EU by deciding 'to prepare the WEU legacy and the inclusion of those functions of the WEU, which will be deemed necessary by the EU to fulfil its new responsibilities in the area of crisis-management tasks.' See WEU Ministerial Council, Luxembourg Declaration, 23 November 1999, para. 4. For more details on the changing relationship between the two international organisations, see R.A. Wessel, 'The EU as a Black Widow: Devouring the WEU to Give Birth to a European Security and Defence 
'capabilities-expectations gap' in the field of the European Security and Defence Policy. ${ }^{25}$ In subsequent steps, the European Council agreed to the institution of new political and military bodies, structures and procedures to ensure political guidance and strategic direction; ${ }^{26}$ the principles for consultation and cooperation with non-European allies and the UN, NATO and other international organisations; ${ }^{27}$ measures to enhance the Union's military and civilian capabilities and timetables for carrying forward work in both domains; ${ }^{28}$ and the adoption of an acquis sécuritaire, ${ }^{29}$ including a European Security Strategy (ESS), the EU's first comprehensive approach to security issues. ${ }^{30}$ Thus, in a very short timeframe, the EU has developed what was needed to create an ability of its own to undertake the full range of the so-called 'Petersberg tasks', as incorporated in Article 17(2) TEU. ${ }^{31}$

\subsection{Hidden dragon}

\subsubsection{First 5 years: age of innocence}

The most striking manifestation - and raison d'être - of the ESDP is the European Union's capacity to back its diplomatic efforts by action on the ground. Since the entry into force of the Treaty of Amsterdam in 1999, Javier Solana, Secretary General and High Representative for the CFSP (SG/HR), supported by his staff at the Council, has made the most of the cautious wording of his tasks in Article 26 TEU. In the Western Balkans, the testing ground par excellence for the CFSP, the European Union, by way of

Policy', in V. Kronenberger, ed., The European Union and the International Legal Order: Discord or Harmony? (The Hague, T.M.C. Asser Press 2001), 405-434.

See C. Hill, 'The Capability-Expectations Gap, or Conceptualising Europe’s International Role', 31 JCMS (1993) 305-328; and C. Hill, 'Closing the Capabilities-Expectations Gap?', in J. Peterson and H. Sjursen, eds., A Common Foreign Policy for Europe: Competing Visions of the CFSP (London, Routledge 1998), 18-38.

See, e.g., S. Duke, 'Peculiarities in the Institutionalisation of CFSP and ESDP', in Blockmans, ed., op. cit., $75-105$.

27 See J. Wouters and T. Ruys, 'UN-EU Cooperation in Crisis Management: Partnership or Rhetoric?', in Blockmans, ed., op. cit., 215-232; M. Reichard, 'The EU-NATO 'Berlin Plus' Agreement: The Silent Eye in the Storm', ibid., 233-253; V. De Graaf and A. Verstichel, 'OSCE Crisis Management and OSCE-EU Relations', ibid., 255-276; D. Thym, 'Interregional cooperation in Crisis Management: EU Support for the AU, ASEAN and Other Regional Organisations, ibid., 277-290; and A. Sari, 'The Conclusion of International Agreements by the European Union in the Context of the ESDP', 57 ICLQ (2008), 53-86.

See, e.g., G. Lindstrom, Enter the EU Battlegroups, Chaillot Paper No. 97 (Paris, EUISS 2007), in particular at 9-12; and J. Schuyer, 'The Civilian Headline Goal 2008: Developing Civilian Crisis Management Capabilities for the EU', in Blockmans, ed., op. cit., 135-142.

See C. Glière, EU Security and Defence: Core Documents 2007 (Vol. VIII), Chaillot Paper No. 112 (Paris, EUISS 2008).

See, e.g., S. Biscop, The European Security Strategy - A Global Agenda for Positive Power (Aldershot, Ashgate Publishing 2005).

31 See more extensively, R.A. Wessel, 'The State of Affairs in European Security and Defence Policy: The Breakthrough in the Treaty of Nice', 8 Journal of Conflict \& Security Law (2003), 265-288. 
its SG/HR, was instrumental in brokering a peace deal between the government and the Albanian separatists in the Former Yugoslav Republic of Macedonia (FYROM) in 2001 and in hammering out the Belgrade Agreement (2002) to prevent the Federal Republic of Yugoslavia (FRY) from falling apart and having a knock-on effect on the precarious balance reached in Kosovo. ${ }^{32}$ The question remained, however, whether such diplomatic constructs could sustain the disintegrative forces at work in the Western Balkans. While NATO continued to secure stability in FYROM ${ }^{33}$ and 'peacekeeping' in the FRY was unthinkable in the wake of Operation Allied Force, it became increasingly clear that the EU was in need of an operational success in the sphere of ESDP to bring much needed balance to its internationally perceived persona of 'an economic giant, political mouse and military worm'. ${ }^{34}$

On 1 January 2003, the EU launched the European Union Police Mission in Bosnia and Herzegovina (EUPM) as its first-ever civilian crisis management operation within the framework of the ESDP. ${ }^{35}$ On 31 March 2003, the EU finally deployed Operation Concordia, its inaugural military mission, to follow up on NATO's efforts to contribute to a stable and secure environment in FYROM. ${ }^{36}$ Since 2003, the EU has affirmed its operational capability through the launching of more than twenty ESDP operations, ${ }^{37}$ mainly in Africa $^{38}$ and in the Western Balkans, ${ }^{39}$ but also in the EU's eastern neighbourhood, ${ }^{40}$ the Middle East, ${ }^{41}$ and Asia. ${ }^{42}$ The EU has acted as a crisis manager in several guises:

- $\quad$ as an honest broker of peace between the parties to a conflict (e.g. Aceh);

32

See S. Blockmans, Tough Love: The European Union's Relations with the Western Balkans (The Hague, T.M.C. Asser Press 2007), at 189-207.

For months, Turkey delayed an agreement within the Atlantic Alliance on EU access to NATO assets and capabilities under the so-called 'Berlin Plus' arrangements so as to enable the EU to take over from NATO while using the latter's 'hardware'. See W. van Eekelen, From Words to Deeds: the Continuing Debate on European Security (Brussels, CEPS/DCAF 2006), at 67-68.

See M. Eyskens, Bron en horizon. Het avondland uit de impasse (Leuven, Lannoo 1985), at 316. See Council Decision 2002/968/CFSP of 10 December 2002 concerning the implementation of Joint Action 2002/210/CFSP on the European Union Police Mission, OJ 2002 L 335/1.

See Council Decision 2003/202/CFSP of 18 March 2003 relating to the launch of the EU military operation in the Former Yugoslav Republic of Macedonia, OJ 2003 L 76/43.

For an up-to-date list, see the website of the Council of the EU, ESDP operations, at $<$ http://www.consilium.europa.eu/cms3_fo/showPage.asp?id=268\&lang=en\&mode=g $>$. For the 'invisible' crisis management operation in Georgia, i.e. the reinforced EUSR Support Team, comprising a Rule of Law follow-up to EUJUST THEMIS and a Border Support Team, entirely ensured through European Community programmes, see F. Hoffmeister, 'Inter-Pillar Coherence in the EU's Civilian Crisis Management', in Blockmans, ed., op. cit., 157-180, at 166, n. 54.

See, e.g., A. Abass, 'EU Crisis Management in Africa: Progress, Problems and Prospects', in Blockmans, ed., op. cit., 327-343.

See, e.g., M. Emerson and E. Gross, eds., Evaluating the EU's Crisis Missions in the Balkans (Brussels, CEPS 2007).

See Hoffmeister, loc. cit., at 163-167 and 170-175.

Ibid.

See S. Baroowa, 'EU Crisis Management in Asia', in Blockmans, ed., op. cit., 345-354. 
- $\quad$ as an assistant to border management (e.g. Moldova/Ukraine);

- $\quad$ as an adviser in justice reform (e.g. Georgia);

- $\quad$ as a trainer of police and prison staff (e.g. Iraq);

- $\quad$ as a security sector reformer (e.g. Guinea-Bissau);

- $\quad$ as a security guarantor during elections (e.g. Democratic Republic of Congo);

- $\quad$ as a peacekeeper on the invitation of a host country (e.g. FYROM);

- as a regional arrangement operating under a mandate by the United Nations Security Council, to counter the threat to international peace and security (posed by, e.g., piracy and armed robberies against vulnerable vessels off the Somali coast - Operation Atalanta) and to assist peacekeeping operations carried out by other international organisations (e.g. Darfur); and

- as a component of an international transitional administration (e.g. Pillar IV in UNMIK).

The EU has never acted in the capacity of enforcer of the peace (like NATO in Kosovo in 1999) nor in defence against an armed attack on its territory.

While most of the early ESDP operations were fairly successful, largely thanks to the fact that they were usually short-term and limited in both scope and size, they have also revealed shortfalls, bottlenecks as well as broader issues in crisis management. They range from 'growing pains', including the creation of the 'brand' of EU crisis management as well as the planning and drawing up of appropriate mandates for ESDP missions, to more enduring challenges such as coherence among EU policies, institutions and instruments, coordination with other international organisations, notably NATO and the UN, and consistency of 'output' ${ }^{43}$ Lessons learned from these ESDP operations should be taken to heart now that the European Union is facing its 'maturity test' as an international crisis manager.

\subsubsection{The next five years: a maturity test}

In spite of the growing pains in the development of ESDP, the European Union has made significant strides in deploying crisis management operations. However, the issue of defining success of the ESDP is no longer measured in terms of merely launching missions, ensuring mission output and gathering operational experience. ESDP is past its age of innocence. The bar is set much higher now. Not only is greater intra- and interinstitutional coordination and cross-pillar coherence required by EU law and policy, ${ }^{44}$ the

43 These issues are well documented. See, e.g., F. Naert, 'ESDP in Practice: Increasingly Varied and Ambitious EU Security and Defence Operations', in M. Trybus and N. White, eds., European Security Law (Oxford, Oxford University Press 2007), 61-101; Emerson and Gross, eds., op. cit.; and T. Hadden, ed., A Responsibility to Assist: Human Rights Policy and Practice in European Union Crisis Management Operations (Oxford/Portland, Hart Publishing 2009).

44 See P. Koutrakos, 'Security and Defence Policy within the Context of EU External Relations: Issues of Coherence, Consistency and Effectiveness', in Trybus and White, eds., op. cit., 249-269; Hoffmeister, loc. cit.; S. Vanhoonacker, 'The European Security and Defence Policy and 
Union is also expected to conduct several operations at the same time, ${ }^{45}$ to carry them out in line with both human rights law and international humanitarian law, ${ }^{46}$ to live up to its promises by accomplishing its tasks, to effect positive change on the ground, and to show that it can take the lead among other international and institutional actors. These issues have become more pressing since the EU embarked on bigger and more difficult ESDP operations, for instance in the high-risk theatres of Kosovo, Afghanistan and Chad. ${ }^{47}$ If such crises are managed badly, then the European Union risks losing its recently found confidence and acquired image as a regional and global actor serving the interest of international peace and security, especially if an ill-prepared and/or under-equipped ESDP operation stumbles into another 'Srebrenica'. In short, the European Union is facing a big maturity test in ESDP. While the stakes are high for the EU, all three of the above-mentioned 'test cases' unfortunately got off to a bad start. ${ }^{48}$

\subsubsection{EULEX KOSOVO}

The biggest and most ambitious civilian ESDP operation to date, the rule of law mission in Kosovo (EULEX KOSOVO), was born in legal uncertainty after protracted international negotiations on the final status for Kosovo failed to culminate in the adoption of a new UN Security Council mandate for the mission in Kosovo. ${ }^{49}$ Attempts

Coherence Challenges in the Council', in Blockmans, ed., op. cit., 145-156; K. Raube, 'European Parliamentary Oversight of Crisis Management', ibid., 181-198; and V. Kronenberger, 'Coherence and Consistency of the EU's Action in International Crisis Management: the Role of the European Court of Justice', ibid., 199-211.

In its Declaration on Strengthening Capabilities of 11 December 2008, the Council mentioned the following ambitions: "two major stabilisation and reconstruction operations, with a suitable civilian component, supported by up to 10,000 troops for at least two years; two rapid-response operations of limited duration using inter alia EU battle groups; an emergency operation for the evacuation of European nationals (in less than ten days), bearing in mind the primary role of each Member State as regards its nationals and making use of the consular lead State concept; a maritime or air surveillance/interdiction mission; a civilian-military humanitarian assistance operation lasting up to 90 days; around a dozen ESDP civilian missions (inter alia police, rule-oflaw, civilian administration, civil protection, security sector reform, and observation missions) of varying formats, including in rapid-response situations, together with a major mission (possibly up to 3000 experts) which could last several years."

See F. Naert, 'Accountability for Violations of Human Rights Law by EU Forces', in Blockmans, ed., op. cit., 375-393; M. Zwanenburg, 'Toward a more Mature ESDP: Responsibility for Violations of International Humanitarian Law by EU Crisis Management Operations', ibid., 395415; and Hadden, ed., op. cit. These ESDP missions will be taken as test cases. It is beyond the confines of this paper to explore other new or ongoing operations (e.g. Atalanta and Althea, resp.). In other cases, the Union failed to intervene at all (e.g. over the 21-day assault of Israel on Gaza at the beginning of 2009) or did not get any further than receiving an invitation to send a toothless EU Monitoring Mission (e.g. in Georgia after its five-day war with Russia in August 2008 - even if it, i.e. France as holder of the EU Presidency at the time, brokered an early ceasefire agreement and showed unity over the condemnation of Russia for its deep incursion into 'Georgia proper'). On the final status talks for Kosovo, the legal fall-out of the decision of the US, the majority of EU Member States (minus Cyprus, Greece, Slovakia, Spain and Romania), neighbouring states and other countries to recognise Kosovo as a sovereign state after it declared its independence from Serbia on 17 February 2008, see C.J. Borgen, 'Kosovo's Declaration of Independence: Self- 
to provide the ESDP mission with such a mandate had been blocked by Russia and China, which emphasised that any Chapter VII operation in Kosovo had to be conducted within the framework of UN Security Resolution 1244 (1999) and that this implied a complete respect for the territorial integrity of Serbia. From the beginning, the US, UK and France have argued that the EU's non-military operation is authorised because Resolution 1244 leaves considerable freedom to UN members and relevant international organisations to establish a military presence in Kosovo and to the UN Secretary General (UNSG) to establish an international civilian presence in Kosovo, with the assistance of relevant international organisations, in order to provide an interim administration. ${ }^{50}$ Taking note of the EU's wish to intervene, the UNSG decided to restructure the international civilian presence by replacing certain elements of UNMIK by EULEX. ${ }^{51}$ While this reconstruction of the international civilian presence was later endorsed in a statement of the President of the Security Council, ${ }^{52}$ it by no means amounts to an official Security Council authorisation of EULEX an sich. From a UN legal perspective, therefore, the position of EULEX KOSOVO is 'rather fragile and redolent of constructive ambiguity. ${ }^{53}$

The Council of the EU made use of the small window of opportunity, between the re-election of the moderate and EU-minded Boris Tadić as President of Serbia on 3 February and the declaration of independence by the Parliamentary Assembly of Kosovo on 17 February 2008, to adopt two Joint Actions, one to create the EULEX mission ${ }^{54}$ and another to appoint Pieter Feith as EU Special Representative, ${ }^{55}$ and to get the mission physically underway on 16 February 2008. ${ }^{56}$ The adoption of the Joint Actions was therefore not yet marred by the divisions between Member States in reaction to the declaration of independence of Kosovo. Thanks to the agreement that the mission would only be staffed on a voluntary basis and the constructive abstention (Art. 23(1) TEU) of

determination, Secession and Recognition', 12 ASIL Insight (2008), available at $<$ http://www.asil.org/insights/2008/02/insights080229.html>; M. Weller, Negotiating the Final Status of Kosovo, Chaillot Paper No. 114 (Paris, EUISS 2008); and J. Ker-Lindsay, Kosovo: The Path to Contested Statehood in the Balkans (London/New York, I.B. Tauris 2009). See UNSC Res. 1244 (1999), paras. 7 and 9 (military presence) and 10 (civilian presence), resp. In fact, the UNSG reported that he was simply informed of the European Commission's unwillingness to continue to finance UNMIK's Pillar IV. See UN Doc. S/2008/354, point 9.

See S/PRST/2008/44, 26 November 2008.

Editorial comments, 'And in the Meantime... Kosovo...', 46 CML Rev. (2009), 377-382, at 381. See also E. Milano, 'Il Trasferimento di Funzioni da UNMIK a EULEX in Kosovo', 91 Rivista di Diritto Internazionale (2008), 967-990.

Council Joint Action 2008/124/CFSP of 4 February 2008 on the European Union Rule of Law Mission in Kosovo, EULEX KOSOVO, OJ 2008 L 42/92.

Council Joint Action 2008/123/CFSP of 4 February 2008 appointing a European Union Special Representative in Kosovo, OJ $2008 \mathrm{~L} \mathrm{42/88.} \mathrm{Feith} \mathrm{is} \mathrm{also} \mathrm{the} \mathrm{head} \mathrm{of} \mathrm{the} \mathrm{International} \mathrm{Civilian}$ Office (ICO) in Kosovo. His mandate was extended by Council Joint Action 2009/317/CFSP of 16 February 2009, OJ 2009 L 46/69.

As reported in R. Goldirova, 'EU Kosovo mission to start Saturday morning', EU Observer, 14 February 2008. 
Cyprus, Greece, Slovakia, Spain and Romania, the Member States that resisted the recognition of independence, it was possible to launch EULEX KOSOVO.

While the emergence of EULEX from the ashes of two years of political wrangling over the final status of Kosovo was in itself quite an achievement of diplomatic skill and manoeuvring, the fact that the mission was born in such legal controversy has had a negative impact on its actual deployment and on its achievements so far. Spain decided to refrain from contributing personnel to the mission. ${ }^{57}$ Much to the dismay of its Allied partners, Spain even decided to withdraw its military forces from NATO's military operation in Kosovo. ${ }^{58}$ Moreover, Russia (at the UN level) and Serbia (at the local level) are blocking the transfer of powers from UNMIK to EULEX KOSOVO and the local authorities, and have thereby made it impossible that the EU's mission was fully deployed as planned, i.e. by 15 June $2008 .^{59}$ Of the 2,000 law enforcement and justice experts initially envisaged for EULEX KOSOVO, not even 400 were on the ground by then. ${ }^{60}$ While EULEX began operations on 8 December 2008, it only reached full operational capability on 6 April 2009, with the vast majority of its staff deployed. ${ }^{61}$ Despite the challenges, the mission began to fulfil its mandate. Some of the early achievements include:

- EULEX judges and prosecutors and their local counterparts having scheduled more than 80 hearings;

- EULEX having completed the first trial at Mitrovica District Court since 19 February 2008;

- EULEX having carried out 13 exhumations and identified the remains of 23 missing people, 18 of which have been returned to their families;

- $\quad$ the Mission having a 24/7 police and customs presence at 'gates 1 and 31';

- the re-establishment of partial customs controls at the northern gates having resulted in a measurable increase in revenue collection and a considerable decrease in oil smuggling. ${ }^{62}$

As reported in 'Spain holds staff from EU Kosovo mission', BalkanInsight, 31 March 2008. As reported by V. Burnett, 'Spain's retreat from Kosovo raises eyebrows', International Herald Tribune, 24 March 2009.

At the international level, Serbia - with strong support from Russia - is actively engaged in blocking Kosovo's accession to the United Nations and other global or regional organizations.

See Summary of intervention of Javier Solana before the meeting of international organizations active on the ground in Kosovo, Council Press Release S 257/08, Brussels, 18 July 2008.

See Yves de Kermabon's speech at inauguration of new EULEX Headquarters, Pristina, 6 April 2009, available at <http://www.eulex-kosovo.eu/?id=8\&n=84>: "With about 3,000 staff, EULEX is bigger than the other 9 civilian operations put together that the EU is currently running throughout the world. This is a major investment on the part of the EU. It was made because the EU is committed to regional stability and to the region's future in the European Union.” Ibid. 
Nevertheless, the political and local opposition to EULEX KOSOVO continues to pose operational challenges for the mission, especially in the de facto separated ethnic Serbian northern Mitrovica and when trying to assure the rights of minority groups throughout the territory of Kosovo. ${ }^{63}$ On orders from Serbia's government, the Kosovo Serbs, who represent some $5 \%$ of the entire population, are refusing to cooperate with Kosovo's government and with EULEX. ${ }^{64}$

Kosovo is, first of all, a European problem, and the European Union has the primary responsibility and interest to stabilize the region. Regrettably, the EU's inability to agree on a common policy has not only weakened its role at the international level, but it has also become a major obstacle to determined action within Kosovo itself. The five EU Member States that continue to withhold recognition of Kosovo in fact encourage those who refuse to offer EULEX KOSOVO any cooperation and, therefore, are impeding the mission's work. That stance also makes it infinitely more difficult for moderate forces in Serbia to adjust to the new situation in Kosovo. Arguably, only a unified EU position, combined with the knowledge that EU accession for Serbia is unthinkable as long as its conflict with Kosovo has not been fully resolved, may over time lead to a change of attitude on the part of both ordinary Serbs and their government. Both Serbia and Kosovo also need a clear European perspective and unhesitating help to meet the daunting challenges they are facing. At the moment, both are missing. ${ }^{65}$

\subsubsection{EUPOL AFGHANISTAN}

In the wider context of the international community's efforts to support Afghanistan in taking responsibility for law and order, the EU has launched a three-year civilian ESDP mission in mid-June $2007 .{ }^{66}$ EUPOL AFGHANISTAN, which builds on the heavily

See Report of the Secretary-General on the United Nations Interim Administration Mission in Kosovo, UN Doc. S/2009/149, 17 March 2009, paras. 6-8. As reported by E. Vucheva, 'Kosovo not yet 'fully' independent, EU envoy says', EU Observer, 11 February 2009.

65 See M. Ahtisaari, W. Ischinger and A. Rohan, 'The EU is coming up short in Kosovo', Daily Star, 18 February 2009; and in a more general sense Blockmans, op. cit., at 312-313: a so-called 'Helsinki moment' should be created for the Western Balkans. This is a reference to the historic decision of the European Council gathered at Helsinki in December 1999 to grant candidate country status to Turkey. In a similar historic spirit, the European Council should use one of its forthcoming summits to review the achievements of the Western Balkans in satisfying the preaccession criteria and grant candidate country status to Albania, Bosnia-Herzegovina, Montenegro, Serbia and Kosovo once all these countries have applied for membership. Council Joint Action 2007/369/CFSP of 30 May 2007 on establishment of the European Union Police Mission in Afghanistan (EUPOL AFGHANISTAN), OJ 2007 L 139/33 (as amended). On 23 March 2007, the UN Security Council adopted Resolution 1746 (2007) on the extension of UN Assistance Mission in Afghanistan's (UNAMA) mandate, which, inter alia, welcomes the decision by the EU to establish a police mission in the field of policing with linkages to the wider rule of law and counter-narcotics, to assist and enhance current efforts in the area of police reform at central and provincial levels. In a letter dated 16 May 2007 the government of Afghanistan invited the EU to launch an EU police mission in Afghanistan. 
criticized efforts of the German Police Project Office ${ }^{67}$ and other international actions in the field of police and the rule of law, is supposed to monitor, mentor, advise and train at the level of the Afghan Ministry of Interior, regions and provinces. The mission is widely regarded as the Union's most visible contribution to the international efforts at stabilising the country. It runs in parallel to NATO's first military mission outside Europe. At the time of writing, the NATO-led International Security Assistance Force (ISAF) was seen by many observers to be failing to such an extent that it risked fracturing the Atlantic Alliance itself. ${ }^{68}$ US President Barack Obama's search for strengthened European engagement to fight $\mathrm{Al}$ Qaeda and the Taliban insurgency on the Afghan/Pakistani ('AfPak') border and to rebuild Afghanistan increased the pressure on EU Member State governments to put the conflict's regional dimension higher up their foreign policy agendas and to step up their military, police and civilian contributions to match their vocal support for the US-led initiatives with troops and kit. Afghanistan thus represents a litmus test for the future of transatlantic relations and for the EU's credibility as a global security actor. 69

Most EU Member State governments, however, remained reluctant to commit significantly more combat troops to ISAF or to remove national restrictions on their deployment. ${ }^{70}$ This was due to public reservations - if not outright opposition - in Member States to the war in Afghanistan, the deteriorating security situation and the remoteness of the theatre. Understandably, it makes it harder to argue the case for more military engagement in what seems to be an endless war far away in a country that has always ejected foreign occupiers. It was only after much cajoling and shaming by the US and NATO that EU Member States, at NATO's 60th Anniversary Summit on 3-4 April 2009, committed 5,000 new troops to the 26,000 already in place, but 3,000 of them would be deployed only temporarily to provide security for the August 2009 elections. $^{71}$

67 As reported by J. Dempsey, 'Germany criticized for its training of Afghan police’, International Herald Tribune, 15 November 2006.

68 See, e.g., M. Williams, 'The militia mistake', The Guardian, 29 December 2008; J. Blitz, 'NATO summit faces Afghan test', Financial Times, 2 April 2009; T. Shanker and S. Erlanger, 'NATO meeting to highlight strains on Afghanistan', New York Times, 3 April 2009; and D. Korski, 'NATO: Keeping in Shape at 60', NATO Review (2009).

See, e.g., S. Islam and E. Gross, 'Afghanistan: Europe’s credibility test', EPC Policy Brief, March 2009; and E. Gross, 'Security Sector Reform in Afghanistan: the EU's Contribution', Occasional Papers No. 78 (EUISS, Paris 2009). In March 2009, the UK, the second-largest contributor to NATO forces with some 8,300 soldiers, said it could not do more and was demanding fairer burden-sharing of responsibilities, particularly in more difficult areas such as the volatile southern province of Helmand. Germany had 3,640 soldiers in the relatively calm north. France sent an additional 1,200 troops in 2008, bringing its total to about 2,800. Italy had 2,350 soldiers; Poland about 1,600; the Netherlands around 1,800. 'National caveats' on when, where and how these troops could be deployed, remained in place, despite complaints that these significantly limit ISAF's operational capability. For an audit of EU Member States' contributions to Afghanistan's reconstruction, see D. Korski, 'Shaping Europe's Afghan Surge', ECFR Policy Brief, April 2009, at 16-19.

71 As reported by S. Erlanger and H. Cooper, 'Europeans offer few new troops for Afghanistan', New York Times, 5 April 2009. 25 EU Member States are deploying troops to ISAF. Germany said 
Obama's calls for a more permanent European troop increase were thus politely brushed aside. By increasing US troops in Afghanistan to some 68,000 by the end of 2009, from 38,000 at the beginning of the year, the character of ISAF has been significantly Americanized. $^{72}$

When EU Ministers of Foreign Affairs in February 2009 promised to forge a 'common approach' with the US to building a stronger and safer Afghanistan, ${ }^{73}$ they probably meant shifting the international focus from military solutions to a more 'comprehensive approach', covering wider security and development issues such as police and judicial training and reform, strengthening Afghanistan's governance and emboldening the counter-narcotics drive. Arguably, these are areas where the EU has more expertise and experience to play a key role. At the same time, this approach puts the onus on the EU to perform. Whereas the EU is already a leading aid donor to Afghanistan, ${ }^{74}$ with police reform now higher up the Afghan security agenda, most expectations and attention will be centred on EUPOL AFGHANISTAN, the Union's highest profile initiative. As Islam and Gross have noted: '[w]hatever else the EU does, its efforts will be judged by the police mission's success or failure. (...) The good news is that EUPOL is now widely recognised as an important component of the international drive for improved security in Afghanistan. The bad news is that its deficiencies mean Europe continues to punch below its weight in the country'. ${ }^{75}$

Launched in 2007, EUPOL aims at contributing to the establishment of sustainable and effective civil policing arrangements that will ensure appropriate interaction with the wider criminal justice system under Afghan ownership. The mission's tasks include working on an Afghan national police strategy, encouraging Interior Ministry reform and training at the level of the central Afghan administrations, regions, provinces and districts. ${ }^{76}$ Nineteen EU Member States plus Canada, Croatia, New Zealand and Norway contribute to the mission. ${ }^{77}$ EUPOL got off to a slow start. Of its initially envisaged 230 personnel, mainly police, law enforcement and justice experts, only around 170 had taken up their post by mid-2008, more than one year after its

it would send an additional 600 troops; Spain offered 600; the UK 900; Italy agreed to add 300 more soldiers; Poland wanted to send an extra 400. A further 1,400 to 2,000 soldiers would be sent to form 'embedded training teams' for the Afghan army and the police.

72

73

See P. Baker and T. Shanker, 'Obama sets new Afghan strategy', New York Times, 27 March 2009.

Council of the EU, Press release 6729/09 (Presse 48), 23 February 2009, at 7.

The combined European Commission and Member State aid to the country for 2002-2006 totalled EUR 3.7 billion. An extra EUR 700 million was earmarked for 2007-2010 in three key priority areas (justice sector reform; rural development, including alternatives to poppy production; and health) and this amount was again topped up with an additional EUR 60 million (20 million for election monitoring in August 2009, 15 million for police training and 24 million for rural development) at the International Conference on Afghanistan in The Hague on 31 March. See European Commission, Press release IP/09/500 of 30 March 2009.

See Islam and Gross, loc. cit., at 3.

Council Joint Action 2007/369/CFSP (as amended), Articles 3 and 4.

Factsheet on the EU Police Mission in Afghanistan (EUPOL AFGHANISTAN), March 2009. 
debut. ${ }^{78}$ They were to be deployed at central, regional and provincial levels but the mission was so poorly prepared that barely three months after EUPOL's inception, its first police chief, Friedrich Eichele, quit due to the lack of furniture, computers and above all - cars, which meant that the initial staff could not leave Kabul and help the training in the provinces. ${ }^{79}$ The decision taken by the Council of Ministers on 26 May 2008 to double the original number of experts working in the mission ${ }^{80}$ is still 'being implemented' in March 2009. ${ }^{81}$ For all the EU's talk about engagement, Member States have been hard-pressed to muster around 400 of their more than 2 million police officers to send to Afghanistan to train a police force of 16,000 which in many provinces is corrupt and predatory. ${ }^{82}$ Member State governments are thus seriously undermining EUPOL's credibility and effectiveness, ${ }^{83}$ especially seeing that the EU's police and justice mission will remain dwarfed by the US police reform programme (CSTC-A), which has committed substantially more resources to police reform (some of which are British, Dutch and German!), sometimes adopting different standards and methods. ${ }^{84}$

Apart from leveraging its contribution to Afghanistan to boost its visibility and credibility internationally, a key challenge for the Union will be one of coordination and cooperation among Member States and between the EC Delegation (European Commission) and the ESDP mission (Council Secretariat), so as to be able to speak with a single voice. Yet, EU Member States appear to be giving priority to upping their national profile in Afghanistan rather than on promoting collective efforts through their flagship mission. Mirroring former Balkans trouble-shooter Richard Holbrooke's appointment as US envoy for 'AfPak', several EU Member States (including the UK, France, Germany and Sweden) have also nominated their own 'AfPak' envoys in addition to the EU Special Representative for Afghanistan, Ettore Francesco Sequi. ${ }^{85}$ The creation of such parallel national positions complicates coordination efforts between the

See EUPOL AFGHANISTAN Press Release 3/2008, 'EUPOL completes deployment in the South', 2 July 2008.

As reported by J. Dempsey, 'Europe lagging in effort to train Afghan police', International Herald Tribune, 28 May 2008.

Council of Ministers, 26-27 May 2008, Press Release 9868/08 (Presse 141), at 29.

Council of Ministers, 16 March 2009, Press Release 7565/09 (Presse 63), at 12.

No less than 14 calls by the EU Council Secretariat for contributions to EUPOL have fallen on deaf ears. See Korski, 'Shaping Europe's Afghan Surge', op. cit., at 9. Islam and Gross note one key problem in this regard, namely that European police experts are more attracted by EULEX KOSOVO than the high-risk operation in Afghanistan, prompting EU Ministers of Foreign Affairs to discuss the possibility of tripling the salaries for those prepared to go to Afghanistan. See Islam and Gross, loc. cit., at 3.

Especially those that have underperformed on military and civilian deployment: Austria, Estonia, Greece, Ireland, Latvia, Lithuania, Malta, Portugal, Romania and Slovenia. Austria, Belgium and Portugal do not even have an accredited resident ambassador in Kabul, a situation that undercuts their governments' proclamations of support for non-military purposes. See Korski, 'Shaping Europe's Afghan Surge', op. cit., at 3 and 5.

Ibid., at 9.

Council Joint Action 2008/612/CFSP of 24 July 2008, OJ 2008 L 197/60; and Council Joint Action 2009/135/CFSP of 16 February 2009, OJ 2009 L 46/61. 
EUSR's office, the Commission Delegation, EUPOL AGHANISTAN in an already crowded theatre. Arguably, setting up an EU 'contact group' on Afghanistan could further confuse the situation, making it even less clear who speaks for Europe. ${ }^{86}$

\subsubsection{EUFOR TCHAD/RCA}

In Resolution 1778 of 25 September 2007 the UN Security Council approved the establishment of a UN Mission in the Central African Republic and in Chad (MINURCAT) and authorised the European Union to deploy its forces in these countries for a period of one year from the time of its declaration of Initial Operating Capability. ${ }^{87}$ However, the initial deployment of the one-year EU operation did not go ahead as planned. In spite of the urgent need to stabilise Chad's borders with Sudan and to protect refugees from Darfur, EU Member States squabbled for months over who should provide troops, helicopters and (medical) equipment, and who should pay the bills. The UK and Germany were unwilling to help with manpower or money because of other commitments, like the war in Afghanistan. Other countries were put off by the expected high maintenance costs of running helicopters, planes and medical aircraft in Chad's dusty environment. In an ironical twist of fate, EU Member States - which had heavily criticised Russia's deep incursion in Georgia during and after the five-day war in August 2008, accepted Moscow's offer to provide four Mi-8 MT utility helicopters (with full supporting equipment and up to 120 personnel) for its EUFOR operation. ${ }^{88}$

But logistics and finances were not the only problems that beset the EU peacekeeping mission for Chad. Military chiefs also proved very cautious about casualties, partly because of the mistrust of Chadian rebels as to the political motives of the main troop-contributing nation and former colonial power, France. ${ }^{89}$ When money, troops and equipment were finally found, the date scheduled for the launching of the

\footnotetext{
86 See Islam and Gross, loc. cit., at 4; and C. Donnelly, 'Europe: scrambling to get it right on Afghanistan', Inter Press Service, 4 April 2009.

87 Council Joint Action 2007/677/CFSP of 15 October 2007 on the European Union military operation in the Republic of Chad and in the Central African Republic, OJ 2007 L 279/21.

88 On 5 November 2008, Javier Solana signed an agreement with the Russian Ambassador to the EU on the participation of the Russian Federation in the operation EUFOR TCHAD/RCA. See Council of the EU, Press release Nr. S357/08.

89 As reported in 'Chad rebels warn EU peace force', EU Observer, 29 November 2007; and Charlemagne, 'Colonial Baggage', The Economist, 7 February 2008: 'A French national force, flying the tricolor, could not credibly pull off a mission sold as a humanitarian intervention, divorced from old-fashioned national interests. (...) The Chad mission has proved a hard sell not because it is too ambitiously European, but because so many EU members suspect it of being a wheeze for advancing French interests. (...) When columns of rebels attacked Chad's capital, the fear in Brussels was not that French troops might be overwhelmed, but that France would intervene so decisively on behalf of the sitting President, Idriss Déby, as to wreck EUFOR's claims to neutrality. (...) Well over half of EUFOR's soldiers will be French, albeit sporting EU shoulder patches and taking orders from an Irish general, Pat Nash. The general told an Irish newspaper that his first challenge would be to "disengage" the (...) mission from the French national presence in Chad. There would be much flying of European flags, he promised.'
} 
EUFOR (28 January 2008) ${ }^{90}$ was pushed further back due to rebel attacks on N'Djamena, Chad's capital. ${ }^{91}$ Even before Operation EUFOR Tchad/RCA reached Initial Operating Capability on 15 March 2008, it suffered its first casualty. ${ }^{92}$ Obviously, this forced the EU to rethink its strategy to secure commitments when troops are being put at risk. ${ }^{93}$ EUFOR's mission, ultimately involving 3,400 troops from 26 EU Member States and a number of third states - the most multinational operation the EU has ever carried out in Africa - ended on 15 March 2009 when UN peacekeepers (a large number of which are ex-EUFOR personnel) took over.

The establishment of EUFOR Tchad/RCA formed part of a comprehensive package of enhanced EU commitment to a regional approach to resolve the crisis in Sudan's troubled Darfur region. ${ }^{94}$ All EU instruments - diplomatic, political, military, humanitarian and financial - have been mobilised in support of this effort. EUFOR's activities included carrying out patrols to observe the security situation in its area of operation (eastern Chad and the north-east of the Central African Republic); protecting civilians in danger, in particular refugees and persons displaced by the fighting in Darfur; facilitating the delivery of humanitarian aid and the free movement of humanitarian personnel; protecting UN personnel, facilities, installations and equipment and ensuring the security and freedom of movement of its staff and UN and associated personnel. As such, these activities helped to speed up the establishment of UNAMID in Darfur, but it is highly questionable whether EUFOR had any impact at all on the efforts by the AU (and the UN) into revitalising the political process with a view to finding a lasting solution. ${ }^{95}$

Given the situation on the ground, the vast area covered and the logistical difficulties, this operation proved a real challenge for the EU. Whereas the Ministers of Defence of the Member States, at their informal meeting in Prague on 12-13 March 2009, stated that the objectives of the EUFOR Tchad/RCA had been 'fulfilled successfully', ${ }^{96}$

90

Council Decision 2008/101/CFSP of 28 January 2008 on the launching of the European Union military operation in the Republic of Chad and in the Central African Republic (Operation EUFOR Tchad/RCA), OJ 2008 L 34/39.

$91 \quad$ EU Presidency Statement on the Republic of Chad, Brussels, 3 February 2008.

92 See EUFOR TCHAD/RCA, Press Release, 10 March 2008.

93

94

95

See A. Mattelaer, 'The Strategic Planning of EU Military Operations - The Case of EUFOR TCHAD/RCA', IES Working Paper 5/2008.

See European Commission, 'Commission to boost support for refugees and displaced people in Chad and the Central African Republic', Press release IP/07/1425, 1 October 2007.
It is thanks to the mediation of Qatar and Libya, the latter in its role as Chairman of the AU, that an initial accord was signed between Sudan and Chad with a view to a normalisation of relations between the two countries. As reported on the website of the Qatari Ministry of Foreign Affairs, 'Sudan and Chad sign the "Doha Accord"', 3 May 2009, $<$ http://english.mofa.gov.qa/newsPage.cfm?newsid=6265>.

As reported in the Press Release of the Czech EU Presidency, 'Informal meeting of EU defence ministers launched in Prague', 12 March 2009, available at <http://www.eu2009.cz/en/news-anddocuments/press-releases/informal-meeting-of-eu-defence-ministers-launched-in-prague-12080/> . See also 'Javier Solana, EU High Representative for the CFSP, prepares the transition from EUFOR TCHAD/RCA to MINURCAT with the UN Special Representative Victor da Silva 
the ESDP operation did not improve the security situation. ${ }^{97}$ The expulsion of 13 humanitarian organisations from the Darfur region and the suspension of their relief efforts, as a consequence of the indictment by the International Criminal Court of the Sudanese President Omar al-Bashir, ${ }^{98}$ led to a massive afflux of refugees into neighbouring Chad and a crisis of even greater dimensions. Arguably, EUFOR's mandate, like that of its successor MINURCAT, was too restricted as it was limited to reducing insecurity in camps for refugees and internally displaced persons and the surrounding areas and did not include, as it needed to, elements to eradicate the root causes of the conflict. ${ }^{99}$

\subsection{Challenges for EU Crisis Management in the Coming Years}

\subsubsection{Introduction}

The EU not only faces legal and political challenges in crisis management that forces it to explain its interpretation of public international law and redefine its approach to both unlike-minded countries, as well as powerful allies demanding a bigger input in operations elsewhere, it also has to ensure that internal political and administrative cohesion is maintained and that operational demands posed by big and increasingly hybrid missions in difficult and dangerous situations are met and are translated into successful action. Last but certainly not least, shortcomings in both budget and capabilities will have to be addressed. ${ }^{100}$ Needless to say, this is huge test for the

Angelo’, Council Press Release No. S039/09, 16 February 2009: “With EUFOR, the European Union decisively contributed to increased security for the civilian populations and humanitarian workers in the region."

For a critical review of EUFOR's mission, see the reading of MEP Geoffrey van Orden (member of the EP's defence subcommittee): 'There is an appalling humanitarian and security situation in Chad. The EU has not managed the right response. (...) The Chad mission would have been more successful and would have had continuity had the UN taken a role from the beginning, instead of acceding to the EU's politically-driven request for military involvement.' In the same vain, Elise Ford, head of Oxfam International's Brussels office, said that '[c]ivilians in eastern Chad need as much protection as they did when the EU force was first deployed a year ago. The underlying security situation has not significantly improved even if part of the population feels safer. (...) Crimes still go unpunished and banditry is a reality that thousands civilians face every day. Sexual violence is increasing and armed groups are free to recruit child soldiers, while inter-ethnic clashes have caused further deaths, left many injured and displaced.' As reported by V. Pop, 'EU mission in Chad ends amid tensions', EU Observer, 12 March 2009. On 4 March 2009, Pre-Trial Chamber I of the International Criminal Court issued the ICC's firstever arrest warrant for a sitting Head of State for war crimes and crimes against humanity. The ICC suspected al-Bashir of being criminally responsible, as an indirect (co-)perpetrator, for intentionally directing attacks against an important part of the civilian population of Darfur, murdering, exterminating, raping, torturing and forcibly transferring large numbers of civilians, and pillaging their property. See ICC Press Release No ICC-CPI-20090304-PR394, 4 March 2009. See ICG, 'Chad: Powder Keg in the East', Africa Report Nr. 149, 15 April 2009. Oxfam called on the EU to work with the African Union to appoint a high-level envoy to re-establish direct talks between the government and the main rebel groups. See Pop, loc. cit.

For some out-of-the-box thinking on these issues, see A. Bailes, 'The Conscription Debate that Europe Shies Away From', 11 Europe's World (2009), 69-72. 
European Security and Defence Policy, the outcome of which will define not just the future of European crisis management, but indeed the very position of the European Union on the international political scene.

\subsubsection{The internal vs. external and soft vs. hard divides in $\mathrm{EU}$ security policies}

A theme which emerges from the 'test cases' elaborated above is that the classic distinctions between internal and external security and hard and soft security no longer apply to the analytical framework in which the issues related to these concepts are approached. What we are observing is a merging of the concepts of internal and external security and a shifting emphasis between soft and hard security.

The first point, i.e. that the internal and external security concepts are both transboundary in nature, is illustrated by, e.g., the need to fight terrorist groups on the AfghanPakistani border in order to better protect the EU's internal security against terrorist attacks and by the need to monitor the transit of natural gas to secure deliveries to the EU in the wake of the dispute between Russia and Ukraine in January 2009 over the payment of supplies. ${ }^{101}$ While it is true that the European integration process has always been a trans-boundary security project, for the first forty years of its existence the EC/EU promoted inter-state security through a system of cross-border networks. External security relations among Member States were turned into 'domestic' EU policies and law. Now, in an era of trans-boundary threats and security challenges, the task of the Union is to defend and boost its security through similar networks beyond the internalexternal divide. But the unhelpful distinction between internal 'securitarisation' of relations between EU Member States and an external Common Foreign and Security Policy, a distinction which originates in the tradition of territorial security and border defence, has been cemented into the EU's pillar structure: the Second Pillar (CFSP) has been set in contrast - politically as well as legally - to the 'internal' security domains of the First Pillar (civil protection, energy, environment, health, etc.) and the Third Pillar (police, border control, etc.). However, the question is to what extent a practical and analytical line between external and internal security can be drawn for an entity set up with the aim to erode borders to enhance inter-state security. The 2003 European Security Strategy (ESS) declares that 'internal and external aspects are indissolubly linked'. ${ }^{102}$

101 See Press Release of 12 January 2009, 'ENERGY: Update on the deployment of EU monitor team in Ukraine', available at http://www.delukr.ec.europa.eu/press_releases.html?y=2009\&m=1 ESS: A Secure Europe in a Better World - European Security Strategy, Brussels, 12 December 2003. In the light of all evolutions which have taken place since its adoption in 2003, in particular the experiences drawn from ESDP missions, the endorsement by the December 2008 European Council of the High Representative's Report on the Implementation of the European Security Strategy - Providing Security in a Changing World - should be welcomed with a view to complement the ESS and to improve its implementation. See European Council, Presidency Conclusions, doc. 17271/08 (CONCL 5), 12 December 2008, point 30, with reference to the Report of the High Representative laid down in doc. 17104/08 (S407/08) of 11 December 2008. The report was written in full association with the Commission and in close cooperation with the 
However, the implications of this merger for the EU's protection are hardly reflected in the making and analysis of European Union security institutions, law, policies, and operational planning. It is widely acknowledged that there is great potential in a more efficient combination of the EU's cross-pillar security policies and capacities. ${ }^{103}$

On the second point raised at the outset of this section, it is clear that, while a lot of (media) attention is devoted to the (problems involved with the) EU increasingly equipping itself for harder-type security missions in higher-risk theatres around the world, the kind of security challenges which it has to deal with more routinely on the European continent have a softer security character (e.g. illegal immigration, organised crime and the disruption of the flow of energy resources). Increasingly though, the distinction between the 'hard' and the 'soft' security nature of EU policies and operations is shifting and, hence, the choice for their legal basis becomes more difficult. This is most strikingly visible in the European Union's Border Assistance Missions (EUBAM) deployed in the EU's neighbourhood and the Security Sector Reform (SSR) missions elsewhere in the world. Whereas the legal basis for EUBAM Moldova/Ukraine was assigned to the First Pillar, ${ }^{104}$ EUBAM Rafah was based on the Second Pillar because of the especially dangerous environment of the Gaza Strip. ${ }^{105}$ EUSEC RD CONGO, the Union's first SSR mission was designed to provide advice and assistance to the Congolese authorities responsible for security, while also taking care to promote policies compatible with human rights and international humanitarian law, democratic standards and the principles of good governance, transparency and respect for the rule of law. ${ }^{106}$ Consultations between the Council and the Commission on the planning of an integrated mission (including a military, a police and a justice component) failed as no compromise could be reached on how to delineate the line of command that could preserve the respective competences of the institutions. As a result, such an integrated mission was never set up. ${ }^{107}$ It was only after a joint assessment mission to the DRC that the Council and the Commission presented a joint paper outlining the EU approach to security sector reform. In the end, the military and police component was entrusted to a Second Pillar

Member States and highlights, for instance, climate change and energy dependence as major security threats.

See, e.g., S. Duke and H. Ojanen, 'Bridging Internal and External Security: Lessons from the European Security and Defence Policy’, 28 Journal of European Integration (2006), 477-494.

EU BAM Fact Sheet, December 2007, available at <http://www.eubam.org>. See Hoffmeister, loc. cit., at 173. For a review of the mission, see X. Kurowska and B. Tallis, 'EU Border Assistance Mission: Beyond Border Monitoring?', in 14 EFA Rev. (2009), 47-64.

Council Joint Action 2005/889/CFSP of 12 December 2005, OJ 2005 L 327/28, Recital 13. Another reason for EUBAM Moldova/Ukraine to be legally based on the First Pillar is that the mission concentrates not only on security-related border and movement issues but also on customs and fiscal matters that are related to Community powers. Council Joint Action 2005/355/CFSP of 2 May 2005, OJ 2005 L 112/20.

See G. Grevi, 'Pioneering Foreign Policy: The EU Special Representatives', Chaillot Paper No. 106, (Paris, EUISS 2007), at 116-117. 
mission, EUPOL RD CONGO, while the mandate for the justice component, EUSEC RD CONGO, was based on the First Pillar. ${ }^{108}$

The finding that the classic distinctions between internal-external and soft-hard security policies are blurring has consequences for the attempts of the Union at achieving more coherence and consistency in policy-making and law-making in the European security field.

\subsubsection{Coherence and consistency; decision-making and leadership}

The notion of coherence refers to the level of internal cohesion, i.e. the level of institutional coordination within the EU. As such, the principle carries a procedural obligation for the institutions to cooperate with each other. ${ }^{109}$ The principle of consistency carries an obligation of result, namely to ensure that no contradictions exist in the external projection of strategies and policies. Achieving more coherence and consistency in policy-making and law-making in the European security domain is not a new challenge but has been heightened. The recent enlargements with ten states from Central and Eastern Europe, Malta and Cyprus have complicated decision-making on EU security policies. Kosovo is a case in point; the definition of relations with Russia another. Also, the Union's new geographical and geopolitical position has brought relations with third countries, especially those on its borders, into sharper focus and is forcing the EU to define its international role and responsibilities more clearly.

Is the current legal framework still conducive to the achievement of consensus on any issue, let alone topics as sensitive as security policies, in an EU numbering 27 Member States (or more)? While the increases in the number of Member States do not seem to really matter in a veto system, as it only takes one state to block a proposal, ${ }^{110}$ the chances of disagreement and delay do increase exponentially as the number of participants rise, particularly on issues that touch on sensitive national security concerns. The EU faces the challenge to ensure that enlargement does not further disrupt internal cohesion and adds to, instead of detracts from, its ability to externally project security and stability. Without efficient decision-making and/or clear leadership, efforts to converge security policies may be futile.

Leadership is needed to ensure that decisions on, for instance, counter-terrorism or launching ESDP missions are made swiftly and to give clear direction to EU security actions in the operational phase. With increasingly diverse interests and approaches to dealing with security issues, the last waves of enlargement have stretched the sense of solidarity and commonality to the maximum. This is best illustrated in the Area of

108

109

Council Joint Action 2007/405/CFSP of 12 June 2007 and Council Joint Action 2007/406/CFSP of 12 June 2007, OJ 2007 L 151/46 and /52, respectively. See Hoffmeister, loc. cit., at 174.

Article 3(2) TEU imposes this obligation on the Council and the Commission. Within the framework of the Second Pillar, it is upon the Council to "ensure the unity, consistency and effectiveness of action by the Union” (Article 13(3) TEU).

See T. Valášek, 'New EU Members in Europe's Security Policy', 18 Cambridge Review of International Affairs (2005), 217-228, at 217. 
Freedom, Security and Justice. As a direct result of enlargement, initiatives by old Member States - such as the G5 meetings of the JHA Ministers of France, Germany, Italy, Spain and the UK and the conclusion on 27 July 2005 of the Treaty of Prüm by seven Member States - briefly heralded the renaissance of conducting business among smaller groupings of like-minded states outside the framework of the EU Treaties. ${ }^{111}$ Yet, leadership and decision-making within the European Union are potentially the hardest issues to resolve, with already extremely sensitive areas further complicated by enlargement. In particular, the rise in the number of small states spells greater opposition to large state dominance.

Leadership is required at three levels: (i) the political drive to crystallise the idea of a security policy; (ii) the institutional responsibility within EU structures; and (iii) the practical administration of EU policy. The lack of leadership at these levels makes it difficult to decide whether a crisis exists, to then determine the scale of the crisis, and to achieve a consensus on the response. This failure was clearly illustrated by the arguments over a military intervention in Iraq. ${ }^{112}$ In addition, without leadership, it will be harder to achieve the reforms needed to close the infamous 'capabilities-expectations gap' in the field of EU security policies. However, talk of leadership immediately raises concerns about the emergence of directoires. ${ }^{113}$ This form of enhanced cooperation consists of a small number of EU Member States, usually the largest and/or most powerful, constituting the core decision-making body. The primary concern is that such a move will marginalise other/smaller Member States. The enlargement of the EU with twelve new Member States has complicated the Union's political balance. The three biggest EU Member States - France, Germany and the UK - continue to be crucial to the EU's security policy formulation, as their efforts to spearhead a resolution of the nuclear dispute with Iran demonstrates. At the next level down, Italy and Spain have been joined by Poland and Romania as medium-sized Member States, demanding a seat at the top table. However, as the majority of new Member States can be classified as 'small states', their security sensitivities in decision-making processes have become an even greater issue. ${ }^{114}$ Due to their markedly Atlanticist orientation, the new Member States have tipped the internal balance of the EU in that direction. But because there is no talk of a Central European 'bloc' - not on the issue of Euro-Atlantic relations, nor for that matter

111 The Treaty of Prüm has in the meantime been incorporated in the EU's acquis. See OJ $2007 \mathrm{C}$ $71 / 35$.

112 The fault lines that opened up across Europe in 2003 over the war in Iraq were ominous signs for the development of a cohesive CFSP and led to Rumsfeld's evocation of 'old' and 'new' Europe. See E. Pond, 'The Dynamics of Alliance Diplomacy over Iraq', EUI Working Papers, RSCA No. 2004/26 (Florence, EUI 2004).

See, e.g., S. Keukeleire, 'Directorates in the CFSP/CESDP of the European Union: A Plea for "Restricted Crisis Management Group”', 6 EFA Rev. (2001), 75-101; T. Jäger, 'Enhanced Cooperation in the Treaty of Nice and Flexibility in the Common Foreign and Security Policy', 7 EFA Rev. (2002), 297-316.

See A. Wivel, 'The Security Challenge of Small EU Member States: Interests, Identity and the Development of the EU as a Security Actor', 43 JCMS (2005), 393-412. 
on any other important security policy, ${ }^{115}$ they will not want any form of directoire to emerge for decision-making on security policies, regardless of what combination of large states that directoire may entail.

This brings us back to the issue of unanimity-based decision-making procedures in the largely intergovernmental security policies of the EU, the outcome of which has been made more difficult by the eastern enlargement. The arguments in the European Convention on the Future of Europe and the pre-Lisbon IGC between medium-sized states, such as Poland and Spain, and the largest states, particularly Germany, over the number of weighted votes in the Council and a double-majority voting system exemplify the sensitivities of the issue. This argument also illustrates how wary some of the new Member States are about being dominated by the older and larger Member States. The intergovernmental nature of decision-making does not foster a sense of commonality. Member States may wield (the threat of) their veto whenever they disapprove, when the position taken is contrary to their interests, when external pressure is exerted upon them or when domestic opposition pressurises the government.

However, the bottom line remains that the willingness of the Member States to act together through 'their' Union is often missing. While pragmatism about the fact that only a united EU can tackle most of the security challenges posed by a globalising world should make the Member States mend their ways, it will depend on vision and political leadership whether they will.

\subsubsection{Sub-conclusion}

Whereas the EU includes the assertion of its own identity on the international scene and the promotion of peace, security and progress in Europe, its neighbourhood, as indeed the world, among its principle mission statements, ${ }^{116}$ it has, so far, not excelled in projecting a picture of itself as a strong international security actor. Both as a 'soft power' and in its approach to harder security issues, the EU is often perceived by others as unstable and weak. ${ }^{117}$ The EU's image problem has been less related to its scale of efforts than to its inherent structural deficiencies. That is not to say that the efforts developed by the EU could not be strengthened. It goes without saying that, e.g., the extension of unconvincing (prospects of) benefits, the adoption of ineffective targeted sanctions, and the formulation of weak mandates of ESDP missions should be prevented and amended where already in existence. It is a positive sign that, in the framework of the ENP, for instance, the Commission has indicated to stand ready to develop, together with the Council, further

For an illustrative conceptualisation and categorisation of EU Member States' positions on Russiarelated topics, see M. Leonard and N. Popescu, 'A Power Audit of EU-Russia Relations', ECFR Policy Paper (ECFR, London 2007).

116 See, e.g., the Preamble and Art. 2 of the TEU; the 2003 ESS, supra n. 5; and the 2004 Strategy Paper on the ENP: Communication from the Commission, European Neighbourhood Policy, Strategy Paper, COM (2004) 373 final. cit. 
proposals in the field of conflict resolution, using both Community and non-Community instruments. ${ }^{118}$ However, the real test of the EU's effectiveness will come at the level of cohesion among Member States. A Union that is divided, and where the biggest countries seek their own selfish interests in bilateral deals with powerful neighbouring states, while the smaller Member States stubbornly block common positions and joint actions to draw attention to their concerns, will achieve little but derision, both at home and abroad. A European Union that unites around clearly defined objectives will stand a much better chance of playing a prominent role on the international scene. In the following section we will investigate to what extent the Lisbon Treaty will be able to counter these difficulties.

\section{EU CRISIS MANAGEMENT AFTER THE LISBON TREATY}

\subsection{The Role of Institutions and Individual Actors}

As stated above, effective crisis management calls for effective decision-making. However, in terms of decision-making in CFSP/CSDP, the Lisbon Treaty will only introduce minor changes. The Council - in its configuration as 'Foreign Affairs Council ${ }^{119}$ - will remain the key decision-making organ, but, unlike the other Council configurations, it shall not be chaired by Member State representatives, but by the High Representative (HR; currently Javier Solana) (Art. 18, par. 3 new TEU). In the new Union qualified majority voting (QMV) is the rule, ${ }^{120}$ except for CFSP, where unanimity continues to form the basis for decisions, "except where the Treaties provide otherwise" (Art. 24, par. 1 new TEU). In that respect it is interesting to point to the fact that apart from the already existing possibilities for QMV under CFSP, ${ }^{121}$ it will become possible for the Council to decide on this basis on a proposal submitted by the HR (Art. 31, par. 2 new TEU). This proposal should, however, follow a specific request by the European

See Communication from the Commission, A Strong European Neighbourhood Policy, COM (2007) 774 final, Brussels, 5 December 2007, at p. 7.

According to Art. 16, par. 6 new TEU, "The General Affairs Council shall ensure consistency in the work of the different Council configurations. It shall prepare and ensure the follow-up to meetings of the European Council, in liaison with the President of the European Council and the Commission.

The Foreign Affairs Council shall elaborate the Union's external action on the basis of strategic guidelines laid down by the European Council and ensure that the Union's action is consistent.” See also Art. 16, par. 4 new TEU: "As from 1 November 2014, a qualified majority shall be defined as at least $55 \%$ of the members of the Council, comprising at least fifteen of them and representing Member States comprising at least 65\% of the population of the Union. A blocking minority must include at least four Council members, failing which the qualified majority shall be deemed attained.”

These exceptions return in Art. 31, par. 2 new TEU and are phrased as follows:

- when adopting a decision defining a Union action or position on the basis of a decision of the European Council relating to the Union's strategic interests and objectives, as referred to in Article 22(1),

- when adopting any decision implementing a decision defining a Union action or position,

- when appointing a special representative in accordance with Article 33. 
Council, in which, of course, Member States can prevent this possibility. In addition QMV may be used for setting up, financing and administrating a start-up fund to ensure rapid access to appropriations in the Union budget for urgent financing of CFSP initiatives (Art. 41, par. 3 new TEU). This start-up fund may be used for crisis management initiatives as well and potentially speeds up the financing process of operations. $^{122}$

So far, most proposals in the area of CFSP came from Member States, with a particularly active role of the Presidency. In that respect it is striking that the Member States are not mentioned in the new Art. 22, par. 2, which refers to joint proposals by the HR and the Commission only. However, this seems to be made up by Art. 30, par. 1, which lays down the more general rule that "Any Member State, the High Representative of the Union for Foreign Affairs and Security Policy, or the High Representative with the Commission's support, may refer any question relating to the common foreign and security policy to the Council and may submit to it initiatives or proposals as appropriate." It is in particular this new role of the Commission that may trigger new possibilities for the EU in its external affairs, including international crisis management. Whereas the Commission so far virtually refrained from making use of its competence to submit proposals on issues in the area of foreign, security or defence policy (Art. 22 TEU), ${ }^{123}$ the creation of the competence to submit joint proposals with the HR may enhance its commitment to this area. This is strengthened by the fact that the person holding the position of HR will at the same time be a member (and even a VicePresident) of the Commission (Art. 17, paras. 4 and 5).

This combination of the functions of High Representative and Vice-President of the Commission is, without doubt, one of the key innovations of the Lisbon Treaty. ${ }^{124}$ The potential impact of this combination on the role of the EU in international affairs lies in the fact that there could be a more natural attuning of different external policies. In other words: the weekly (breakfast) meetings between the Commissioner for External Affairs and the HR can be replaced by a breakfast for one. At the same time, the continued separation between CFSP and other Union issues may very well lead to a need

122 See also 'The Lisbon Treaty and its Implications for CFSP/ESDP', Briefing Paper, European Parliament, DG for External Policies of the Union, Policy Department, February 2008, p. 3. Nevertheless, for some Member States, resort to the EU budget may remain attractive, even if this means delaying the EU's response. See Whitman and Juncos, op. cit., at 39. See D. Spence, 'The Commission and the Common Foreign and Security Policy', in D. Spence (Ed.), The European Commission ( $3^{\text {rd }}$ ed.), London: John Harper, 2006. Spence quotes former Commissioner Chris Patten on this issue to provide the reason: "Some of my staff [...] would have preferred me to have a grab for foreign policy, trying to bring as much of it as possible into the orbit of the Commission. This always seemed to me to be wrong in principle and likely to be counterproductive in practice. Foreign policy should not in my view [...] be treated on a par with the single market. It is inherently different” (at p. 360).

More extensively: C. Kaddous, op.cit. Cf. also Whitman and Juncos, op. cit., at 32; and J. Paul, 'EU Foreign Policy after Lisbon: Will the New High Representative and the External Action Service Make a Difference?', 2 Centre for Applied Policy Research (CAP) Policy Analysis. 
for different legal bases for decisions, and hence for the use of distinct CFSP and other Union instruments. This does not only hold true for the outcome of the decision-making process, but also for the process itself, where both the relevant Commission DG and the CFSP section in the Council Secretariat continue to exist. Much will depend on the way in which the legal provisions will be used. Over the past fifteen years, practice revealed a process of 'institutional dynamics' in which a growing together of Community and CFSP decision-making and institutional involvement proved unavoidable. ${ }^{125}$ Interestingly enough, the HR may continue its functions even in case all Commission members are forced to resign following a motion of censure from the European Parliament (Art. 17, par. 8 new TEU).

With regard to the European Parliament and its influence on the Union's role in the world, its position will not change substantially. Apart from the rule that the High Representative and the other members of the Commission shall be subject as a body to a vote of consent by the European Parliament (Art. 17, par. 7), the task of consulting the European Parliament 'regularly' on CFSP issues moves from the Presidency to the HR (Art. 36 new TEU). This shift is related to the creation of the position of a fixed Presidency of the European Council, which replaces the current system of rotating Presidencies (Art. 15, par. 5 new TEU). One could argue that this is a further step in the ongoing 'Brusselization' that one could witness in relation to CFSP over the past years, in line with the replacement of the Political Committee by the permanent Brussels based Political and Security Committee (PSC) and the increased role of the Council Secretariat. ${ }^{126}$ As 'legislative' acts are excluded from the area of CFSP, the formal influence of the European Parliament continues to stand in stark contrast to its competences in other policy areas.

Indeed, whereas Article 16 (new) provides that the Council shall, jointly with the European Parliament, exercise legislative and budgetary functions, Art. 24 makes clear that CFSP is subject to "specific rules and procedures" and that the "adoption of legislative acts shall be excluded". This seriously limits the formal role of the EP in the CFSP decision-making process. At the same time it continues the complexity in situations where (perhaps of the basis of a joint proposal by the Commission and the HR) decisions need to cover both CFSP and other Union issues. In those cases, the 'specific rules and procedures' in CFSP would necessarily result in two (or more) separate

See also R. Gosalbo Bono, 'Some Reflections on the CFSP Legal Order', CML Rev., 2006, pp. 337-394, who even refers to "progressive supranationalism" in relation to the development of CFSP (at 349). More extensively and for further references: R.A. Wessel, 'The Dynamics of the European Union Legal Order: An Increasingly Coherent Framework of Action and Interpretation', European Constitutional Law Review, 2009, No. 1, pp. 117-142.

Cf. S. Duke and S. Vanhoonacker, 'Administrative Governance in CFSP', EFA Rev., 2006, pp. 163-182; and A.E. Juncos and Chr. Reynolds, 'The Political and Security Committee: Governing in the Shadow', EFA Rev., 2007, pp. 127-147. 
decisions on the basis of different legal bases, which again complicates the relation with third states and other international organizations. ${ }^{127}$

Although not termed 'legislative acts' the CFSP instruments are 'decisions', which - despite their 'non-legislative' nature - continue to be binding on the Member States, or as phrased in Art. 28: they "shall commit the Member States in the positions they adopt and in the conduct of their activity”. The familiar labels 'Joint Action' and 'Common Position' will disappear, although all three current forms of CFSP decisions will reappear: the new CFSP 'decisions' may define (i) actions to be undertaken by the Union; (ii) positions to be taken by the Union; (iii) arrangements for the implementation of the decisions referred to in points (i) and (ii) (Art. 25 new TEU). The somewhat unclear - and unnecessary - difference between Joint Actions and Common Positions thus comes to an end, which again adds to a further streamlining of CFSP.

The separation of CFSP is also reflected in the continued exclusion of the European Court of Justice in CFSP matters. However, Art. 24 new TEU provides that this is "with the exception of its jurisdiction to monitor compliance with Article 40 of this Treaty and to review the legality of certain decisions as provided for by the second paragraph of Article 275 of the Treaty on the Functioning of the European Union.” Art. 40 , first of all, reflects to the current 'preservation of the acquis communautaire' clause and states that the implementation of CFSP shall not affect the other policy areas of the Union and vice versa. Article 275 TFEU provides the other exception and allows for the Court to review the legality of decisions providing for restrictive measures against natural or legal persons (the famous sanctions against persons and groups on the anti-terrorism lists of the EU).

Most of the institutional changes in the Lisbon Treaty relate to the position of the High Representative for the Common Foreign and Security Policy, which will be renamed to High Representative of the Union for Foreign Affairs and Security Policy. This name change reflects the fact that it has become clear that the HR indeed represents the Union and not the (collective) Member States. His (or her) competences are clearly laid down in the Union treaty and form part of the institutional framework. Although the term 'Foreign Minister', which was used in the Constitutional Treaty, has been abandoned, the new provisions make clear that the HR will indeed be the prime representative of the Union in international affairs. Even the President of the European Council (note: not the European Union) will exercise its external competences "without prejudice to the powers of the High Representative of the Union for Foreign Affairs and Security Policy.” (Art. 15, par. 6(d)). The HR is to be appointed by the European Council (with the agreement of the President of the Commission) by qualified majority voting. This again underlines his role as Union representative, who is competent to act even in

127 See further on the complex division of external competences within the Union: C. Hillion and R.A. Wessel, 'Competence Distribution in EU External Relations after ECOWAS: Clarification or Continued Fuzziness', 46 CML Rev. (2009), 551-586. 
the absence of consensus among the Member States. The HR is to "conduct" the Common Foreign, Security and Defence Policy; he shall contribute by his proposals to the development of that policy, and preside over the Foreign Affairs Council (Art. 18 new TEU). In addition, his de facto membership of the European Council is codified in Art. 15 new TEU (although strictly speaking it is stated that the HR only 'takes part in the work' of the European Council). He is to assist the Council and the Commission in ensuring the consistency between the different areas of the Union's external action (Art. 21 new TEU) and together with the Council ensures compliance by the Member States of the CFSP obligations (Art. 24, par. 3 new TEU). All in all, the position of High Representative has been upgraded to allow for a stronger and more independent development and implementation of the Union's foreign, security and defence policy, which - potentially - allows for a more coherent and more effective role for the EU in international affairs.

\subsection{New Competences in Defence Policy?}

\subsubsection{A Collective Defence Obligation?}

As we have seen effective crisis management also depends on the potential of the EU to formulate a security and defence policy. The Nice Treaty provided a basis for a European Security and Defence Policy through a modification of Article 17 TEU. Whereas originally the implementation of EU decisions with defence implications was left to the Western European Union (WEU), the Nice Treaty deleted all references to the WEU. From that moment on the Union had been given the competence to operate within the full range of the Petersberg tasks: "humanitarian and rescue tasks, peacekeeping tasks and tasks of combat forces in crisis management, including peacemaking" (Article 17, paragraph 2). In that respect it is odd that Article 17 still refers to the "progressive framing of a common defence policy" after that same policy has entered into force on the basis of the same article. Provisions like these reveal the fact that, although a final consensus was reached on a European Security and Defence Policy, some member states are more eager to lay everything down in treaty arrangements than others. Nevertheless, one cannot overlook the gradual development from the first provision in the Maastricht Treaty ("the eventual framing of a common defence policy, which might in time lead to a common defence"), to the Amsterdam Treaty ("the progressive framing of a common defence policy, which might lead to a common defence"), and finally to Nice were all references to the WEU were deleted, thereby making the EU itself responsible for the elaboration and implementation of decisions and actions which have defence implications.

The Lisbon Treaty can certainly be seen as a further step in this development. For the first time a special Title is devoted to the Common Security and Defence Policy (Chapter 2, Section 2 of the new TEU). On the basis of Article 42 
The common security and defence policy shall be an integral part of the common foreign and security policy. It shall provide the Union with an operational capacity drawing on civilian and military assets. The Union may use them on missions outside the Union for peace-keeping, conflict prevention and strengthening international security in accordance with the principles of the United Nations Charter. The performance of these tasks shall be undertaken using capabilities provided by the Member States.

The Petersberg tasks have been extended to, inter alia, include:

joint disarmament operations, humanitarian and rescue tasks, military advice and assistance tasks, conflict prevention and peacekeeping tasks, tasks of combat forces in crisis management, including peace-making and post-conflict stabilisation. All these tasks may contribute to the fight against terrorism, including by supporting third countries in combating terrorism in their territories.

The references to 'joint disarmament operations', 'military advice and assistance tasks', 'post-conflict stabilisation' and 'the fight against terrorism' in Article 43, paragraph 1 are new and allow the Union to further develop its security and defence policy.

Crisis management may also be needed in relation to an attack on the Union itself. However, with regard to the 'defence' part of CSDP, the Treaty remains ambiguous. The current provision reappears in the new Treaty: "The common security and defence policy shall include the progressive framing of a common Union defence policy. This will lead to a common defence, when the European Council, acting unanimously, so decides.” (Art. 42, par. 2 new TEU). Nevertheless, the Lisbon Treaty does offer reasons to conclude that something has changed. First of all - and despite the claim that a 'common defence' is not yet included in CSDP - Article 42, paragraph 7 provides the following:

If a Member State is the victim of armed aggression on its territory, the other Member States shall have towards it an obligation of aid and assistance by all the means in their power, in accordance with Article 51 of the United Nations Charter. This shall not prejudice the specific character of the security and defence policy of certain Member States.

Taking into account that according to the Helsinki (1999) and Laeken (2001) Declarations "the development of military capabilities does not imply the creation of a European army", it is puzzling what it is the European Council will have to decide on. One may argue that we are not yet dealing with strict obligations for all Member States. This would be confirmed by the second part of paragraph 7 which states that "Commitments and cooperation in this area shall be consistent with commitments under the North Atlantic Treaty Organisation, which, for those States which are members of it, remains the foundation of their collective defence and the forum for its implementation." While this would indeed allow the 'neutral' states Austria, Finland, Ireland and Sweden, 
not to participate, the collective defence obligation does not really differ from Article 5 of the NATO Treaty or Article V of the WEU Treaty. ${ }^{128}$

The feeling that something similar to a collective defence obligation has been created (although somewhat hidden in par. 7 of Art. 42) becomes stronger when the socalled 'solidarity clause' is taken into account. ${ }^{129}$ It is somewhat peculiar that this clause is separated from the collective defence clause and is included in the TFEU (Art. 222) rather than together with the ESDP provisions in the TEU. The clause does not restrict common defence to 'armed aggression', but in fact extends the obligation to terrorist attacks:

The Union and its Member States shall act jointly in a spirit of solidarity if a Member State is the object of a terrorist attack or the victim of a natural or man-made disaster. The Union shall mobilise all the instruments at its disposal, including the military resources made available by the Member States, to:

(a) - prevent the terrorist threat in the territory of the Member States;

- protect democratic institutions and the civilian population from any terrorist attack;

- assist a Member State in its territory, at the request of its political authorities, in the event of a terrorist attack;

(b) assist a Member State in its territory, at the request of its political authorities, in the event of a natural or man-made disaster.

Paragraph 2 adds the following:

Should a Member State be the object of a terrorist attack or the victim of a natural or man-made disaster, the other Member States shall assist it at the request of its political authorities. To that end, the Member States shall coordinate between themselves in the Council.

Paragraph 3 refers to a coordinating role of the Council as well as the procedure: the arrangements for the implementation of the solidarity clause shall be defined by a decision adopted by the Council acting on a joint proposal by the Commission and the HR.

$128 \quad$ Art. 5 of the North Atlantic Treaty reads: "The Parties agree that an armed attack against one or more of them in Europe or North America shall be considered an attack against them all and consequently they agree that, if such an armed attack occurs, each of them, in exercise of the right of individual or collective self-defence recognised by Article 51 of the Charter of the United Nations, will assist the Party or Parties so attacked by taking forthwith, individually and in concert with the other Parties, such action as it deems necessary, including the use of armed force, to restore and maintain the security of the North Atlantic area. [...]"

Art. V of the modified Brussels Treaty (WEU) reads: "If any of the High Contracting Parties should be the object of an armed attack in Europe, the other High Contracting Parties will, in accordance with the provisions of Article 51 of the Charter of the United Nations, afford the Party so attacked all the military and other aid and assistance in their power.”

The idea that the decision on a mutual defence commitment was deliberately taken is confirmed by the fact that this point was already subject to debate during the Convention on the Future of Europe, which prepared the 2004 Constitutional Treaty, It was acknowledged that the current formula in the TEU matches the guarantee of the Brussels Treaty and goes beyond it with a reference to NATO. See 'The Lisbon Treaty and its Implications for CFSP/ESDP', op.cit. 
While the wording of the solidarity clause leaves room for both the Member States and the Council regarding the type and scope of their reaction, it may be seen as an innovation to the current legal regime, where no obligations for the Member States or competences of the Council form part of the treaties. However, after the Madrid terrorist attacks in March 2004, the European Council issued a 'Declaration on Solidarity Against Terrorism', ${ }^{130}$ in which the solidarity clause was already incorporated, although the Declaration does not refer to a role for the Union as such, but to the "Member States acting jointly." In addition, the Declaration leaves it to the Member States to "choose the most appropriate means to comply with this solidarity commitment.”

\subsubsection{A European Army?}

Some of the shortcomings in current EU crisis management seem to relate to the ad hoc implementation of ESDP. The Lisbon Treaty aims to counter this with the introduction of some form of institutionalisation of procedures, formats and (civil and military) capabilities. First of all a new form of ad hoc flexibility is introduced by Article 44 new TEU: "the Council may entrust the implementation of a task to a group of Member States which are willing and have the necessary capability for such a task". This allows the Union to implement its CSDP by sub-contracting it to 'coalitions of the able and willing'. An early example of this arrangement can be found in Operation Artemis, in which France took the iniative to form a group of EU Member States and other states to assist the UN operation MONUC in the Democratic Republic of Congo.

A second form of institutionalisation may be found in paragraph 6 of Article 42, which introduces the notion of 'permanent structured cooperation' for 'those Member States whose military capabilities fulfil higher criteria and which have made more binding commitments to one another in this area with a view to the most demanding missions." ${ }^{131}$ The permanent structured cooperation is further elaborated by Article 46 and by a special Protocol. According to this Protocol the permanent structured cooperation can be seen as an institutionalised form of cooperation in the field of defence policy between able and willing Member States. In that sense it may be regarded as a special form of enhanced cooperation, although the term is not used. It shall be open to any Member State which undertakes to (Article 1):

(a) proceed more intensively to develop its defence capacities through the development of its national contributions and participation, where appropriate, in multinational forces, in the main European equipment programmes, and in the activity of the Agency in the field of defence capabilities development, research, acquisition and armaments (European Defence Agency), and

(b) have the capacity to supply by 2010 at the latest, either at national level or as a component of multinational force groups, targeted combat units for the missions planned, 
structured at a tactical level as a battle group, with support elements including transport and logistics, capable of carrying out the tasks referred to in Article 43 of the Treaty on European Union, within a period of 5 to 30 days, in particular in response to requests from the United Nations Organisation, and which can be sustained for an initial period of 30 days and be extended up to at least 120 days.

Obviously, no reference is made to the creation of a 'European army'. Any explicit hints in that direction would have been unacceptable for certain Member States. Nevertheless, the tasks of the participating Member States come close to at least a harmonisation of the different national defence policies. According to Article 2 of the Protocol, Member States undertake to:

(a) cooperate, as from the entry into force of the Treaty of Lisbon, with a view to achieving approved objectives concerning the level of investment expenditure on defence equipment, and regularly review these objectives, in the light of the security environment and of the Union's international responsibilities;

(b) bring their defence apparatus into line with each other as far as possible, particularly by harmonising the identification of their military needs, by pooling and, where appropriate, specialising their defence means and capabilities, and by encouraging cooperation in the fields of training and logistics;

(c) take concrete measures to enhance the availability, interoperability, flexibility and deployability of their forces, in particular by identifying common objectives regarding the commitment of forces, including possibly reviewing their national decision-making procedures;

(d) work together to ensure that they take the necessary measures to make good, including through multinational approaches, and without prejudice to undertakings in this regard within the North Atlantic Treaty Organisation, the shortfalls perceived in the framework of the 'Capability Development Mechanism';

(e) take part, where appropriate, in the development of major joint or European equipment programmes in the framework of the European Defence Agency.

Moreover, the 'Headline Goal 2010' includes the establishment of so-called 'battlegroups': "force packages at high readiness as a response to a crisis either as a stand-alone force or as part of a larger operation enabling follow-on phases." On decision making, the ambition of the EU is to be able to take the decision to launch an operation within 5 days of the approval of the so-called Crisis Management Concept by the Council. On the deployment of forces, the ambition is that the forces start implementing their mission on the ground, no later than 10 days after the EU decision to launch the operation. In practice this seems to come close to what could be called an 'army', irrespective of the fact that - for political reasons - the documents stressed that the

concept would not amount to "the creation of a European army". Interestingly enough this phrase does not return in the Lisbon Treaty.

\subsection{The Place of CFSP and ESDP in the new Treaty Structure: Continued Inconsistency in Crisis Management?}

As we have seen, the Common Foreign, Security and Defence Policy will remain part of the TEU (and not of the TFEU) and will thus continue to have a separate status in EU 
law. At the same time the original CFSP tasks will be supplemented by a number of new purposes (below in our italics) which occasionally go beyond CFSP stricto sensu. Article 21 of the new TEU provides:

The Union shall define and pursue common policies and actions, and shall work for a high degree of cooperation in all fields of international relations, in order to:

(a) safeguard its values, fundamental interests, security, independence and integrity;

(b) consolidate and support democracy, the rule of law, human rights and the principles of international law;

(c) preserve peace, prevent conflicts and strengthen international security, in accordance with the purposes and principles of the United Nations Charter, with the principles of the Helsinki Final Act and with the aims of the Charter of Paris, including those relating to external borders;

(d) foster the sustainable economic, social and environmental development of developing countries, with the primary aim of eradicating poverty;

(e) encourage the integration of all countries into the world economy, including through the progressive abolition of restrictions on international trade;

(f) help develop international measures to preserve and improve the quality of the environment and the sustainable management of global natural resources, in order to ensure sustainable development;

(g) assist populations, countries and regions confronting natural or man-made disasters; and

(h) promote an international system based on stronger multilateral cooperation and good global governance.

On the basis of these principles and objectives, the European Council will identify the strategic interests and objectives of the Union, which will relate to both the common foreign and security policy and to other areas of the external action of the Union (Art. 22 new TEU). However, for parts falling under the CFSP, the High Representative of the Union for Foreign Affairs and Security Policy will be responsible for proposals for Council decisions, whereas for other areas of external action it will be the Commission. Article 22, paragraph 2 does, however, seem to call for joint proposals, which would force the HR and the Commission to produce a consistent plan, thereby adhering to the demand that "The Union shall ensure consistency between the different areas of its external action and between these and its other policies.” (Art. 21, par. 3). ${ }^{132}$

From the outset (the 1992 Maastricht Treaty), consistency problems were the obvious consequence of the choice for a pillar structure in which both the EU and the EC had separate external competences and decision-making procedures. The division between political (CFSP) and other/economic (EC) external relations was never easy to make, but at the same time the Union and the Community were forced to use different instruments and decision-making procedures, thereby challenging the Union's potential as a cohesive force in international relations. There are numerous examples in which the institutional separation between CFSP and EC led to problematic decision-making and

132 Cf. also Art. 30 new TEU, which refers to "the High Representative with the Commission’s support”. 
unclear situations for third parties. ${ }^{133}$ Apart from the cases concerning the anti-terrorism measures against individuals, ${ }^{134}$ the recent ECOWAS judgment again revealed the difficulties in separating foreign and security policy from other external policies. The case provided the first opportunity for the Court of Justice to speak out on a legal base conflict between the first (EC) and second (CFSP) pillars, ${ }^{135}$ and to shed some light on the distribution of competence between the EC and the EU qua CFSP. In the event, the Grand Chamber of the Court found, unexpectedly for some and notably for the Advocate General, that by using a CFSP Decision on the EU support to ECOWAS (Economic Community of West African States) in the fight against the proliferation of small arms and light weapons (SALW), the Council had encroached upon the EC competence in the field of development cooperation, thus violating the provisions of Article 47 TEU. ${ }^{136}$ The Court preserved the acquis communautaire in the classic manner and argued that once foreign and security policy elements can be based on the European Community Treaty, they should not be based on CFSP. ${ }^{137}$ Even more, the trend towards a more equal position of the CFSP ${ }^{138}$ (with its provisional peak in the new Art. 40 after Lisbon; infra) seems to have been halted now that it is being envisaged that parts of the foreign and security policy be based on Community law once the latter allows for it, or be dealt with by the Member States acting individually or collectively. And, in view of the (established) scope of development policy, this should not be too difficult. The wide interpretation of development policy may not only have an effect on the effet utile of CFSP, but also on the consistency of EU external relations in general as ECOWAS may have taught the Council to be more careful with references to Community measures or tasks in its CFSP (and PJCCM) decisions. It may also have warned Member States that allowing the Union

133 More extensively and for further references: R.A. Wessel, 'The Inside Looking Out: Consistency and Delimitation in EU External Relations' (2000) 37 CMLRev 1135; as well as R.A. Wessel, 'Fragmentation in the Governance of EU External Relations: Legal Institutional Dilemmas and the New Constitution for Europe' in JW de Zwaan et al, (eds), The European Union - An Ongoing Process of Integration, Liber Amicorum Fred Kellermann (The Hague, T.M.C. Asser Press, 2004) 123.

134 See for instance Cases T-306/01, Ahmed Ali Yusuf and Al Barakaat International Foundation v. Council and Commission; T-315/01, Yassin Abdullah Kadi v. Council and Commission, 21 September 2005; T-47/03 Sison and T-327-03 Al-Aqsa, 11 July 2007; T-228/02, Organisation des Modjahedines du people d'Iran v Council, 12 December 2006 [update]

The Court has in the past only been asked to test the compatibility of 'third pillar' measures with Article 47 TEU: Case C-170/96 Commission v. Council (Airport transit visa) [1998] ECR I-2763, paras 15-16; Case C-176/03 Commission v Council (Environmental penalties) [2005] ECR I-7879; Case C-440/05 Commission v Council (Ship Source Pollution) [2007] ECR I-1657; further, see: C. Hillion and R.A. Wessel, "Restraining External Competences of EU Member States under CFSP", in M. Cremona and B. De Witte (Eds.), EU Foreign Relations Law: Constitutional Fundamentals (Hart Publishing, Oxford, 2008), pp. 79-121. See also F. Hoffmeister, ‘Entwicklungszusammenarbeit und andere Politikbereiche’, Europarecht (2008) Beiheft 2, pp. 55-101 More extensively: C. Hillion and R.A. Wessel, 'Competence Distribution in EU External Relations after ECOWAS: Clarification or Continued Fuzziness?’, CML. Rev., 2009, pp. 551-586. Cf. R.A.Wessel, 'The Dynamics of the European Union Legal Order: An Increasingly Coherent Framework of Action and Interpretation', European Constitutional Law Review, 2009, No. 1. 
to act qua CFSP may be harmful in areas where they enjoy a shared competence and it may trigger the Commission to come up with additional claims in other borderline areas. ECOWAS may thus prevent the smooth operation of a system of external relations where cooperation is more important and rewarding in terms of output, than competence competition.

This judgment, together with the continued separate legal regime for foreign, security and defence policy within the European Union, makes it difficult to improve the Union's consistency in its external actions. Nevertheless, the Lisbon Treaty introduces a new delimitation provision in Article 40 new TEU, which not only underlines the need for a preservation of the acquis communautaire (as in current Art. $47 \mathrm{TEU}$ ), but seems to add that the CFSP competences should also be respected:

\footnotetext{
"The implementation of the common foreign and security policy shall not affect the application of the procedures and the extent of the powers of the institutions laid down by the Treaties for the exercise of the Union competences referred to in Articles 3 to 6 of the Treaty on the Functioning of the European Union.

Similarly, the implementation of the policies listed in those Articles shall not affect the application of the procedures and the extent of the powers of the institutions laid down by the Treaties for the exercise of the Union competences under this Chapter” (CFSP).
}

Thus, this provision no longer subjects CFSP to any Community competence, but equally calls for all other policies not to affect CFSP. One could argue that this provision places CFSP on an equal footing as other Union policies and at least no longer puts other Union policies in a default setting. At the same time similar internal delimitation problems as the ones we saw in ECOWAS, may continue to hamper effective external action.

Crisis management is not only done by using CFSP/ESDP measures. The classic example of a cross-pillar policy - economic sanctions - returns in Article 215 of the new TFEU. As in the current Article 301 TEC, economic (and financial) sanctions may only be imposed after a CFSP decision to that end has been taken. An innovation can be found in the rule that the final legislation to that end can only be adopted by the Council (acting by a qualified majority) on a joint proposal by the HR and the Commission. The involvement of the HR in this procedure may guarantee an even better combination of political and economic questions. In addition, paragraph 2 makes clear that restrictive measures cannot only be imposed on states but also "against natural or legal persons and groups or non-State entities.” Finally, the debate on the legal protection of individuals and groups on sanctions lists resulted in a new paragraph: " 3 . The acts referred to in this Article shall include necessary provisions on legal safeguards.”

All in all, the Lisbon Treaty seems to offer a number of improvements which may compensate for the choice to separate the foreign, security and defence policy from other external policies (including trade and economic, social and environmental development). In that respect one can point to the broader objectives of the new CFSP and CSDP and the possibilities for the High Representative in his double-hatted function to combine 
security and military measures with the 'softer' crisis management measures which from part of other Union policies.

\section{CONCLUSION: AN EFFECTIVE ROLE FOR THE EU IN INTERNATIONAL CRISIS MANAGEMENT?}

When we assume that the phrase "improving the coherence of its action" in the preamble of the Lisbon Treaty refers primarily to the Union's role in international affairs, it is indeed this aspect that needs to be assessed. The case studies of some key ESDP missions revealed that the classic distinctions between internal-external and soft-hard security policies are blurring. Yet, the institutional structures do not seem to reflect this fact. The pillar structure introduced an inherent risk of inconsistency by dividing the Union's external relations over two different legal treaty regimes. In that respect the fact that CFSP will still be in another treaty than all other Union policies may be seen as a missed opportunity. Both with regard to the decision-making procedures and the available instruments it will remain difficult to combine CFSP with other Union policies; which means that part of the Union's energy in international relations, including crisis management, will continue to be devoted to internal delimitation questions. ${ }^{139}$ After all, as a result of the complete 'communitarisation' of PJCCM, there will be a more uniform decision-making regime in the other parts of the Union: more impetus will be given to qualified majority voting and the application of the co-decision procedure with the European Parliament. Apart from an adaptation of the so-called 'constructive abstention' provision the unanimity principle for decision-making with regard to CFSP/ESDP has been maintained. This means that consensus-building among 27 (or more) Member States should become easier in the field of internal security policies but remain elusive in the field of external security policies.

On the other hand, the above analysis reveals that a number of things will change in CFSP and that the Lisbon Treaty can certainly be seen as yet another step in the ongoing integration process in this policy field. The upgraded role of the High Representative is certainly the most innovating aspect. Apart from his extensive role as the key representative of the Union in (all) international affairs, his function has the potential of bridging the currently existing divide between Community and CFSP external relations. The same holds true for the future European External Actions Service, although at this stage it is far from clear what its competences will entail. These 'consolidating' developments are, however, conflicted by the choice to continue to divide the Union's external representation over different institutional actors. It is therefore

139 A slightly more positive conclusion on the contribution of the Lisbon Treaty to external consistency is drawn by J. Wouters, D. Coppens, and B. De Meester, 'The European Union's External Relations after the Lisbon Treaty’, in Griller and Ziller, op.cit., pp. 143-203. 
debatable whether the Lisbon Treaty - if and when it enters into force - will improve both leadership and decision-making in the realm of EU security policies. The introduction of a High Representative of the Union for Foreign Affairs and Security Policy, while initially controversial, may improve leadership, especially when duly assisted by the European Commission, of which s/he will be one of the Vice-Presidents, and the European External Action Service. Then again, much will depend on the High Representative's rapport with the newly created President of the European Council, who will also be responsible for the external representation of the EU on issues concerning the Common Foreign and Security Policy. The delineation of responsibilities of both personalities is far from clear, at least on the basis of the text of the Lisbon Treaty. In addition, there are two other authorities responsible for representing the Union to the outside world: the rotating Presidency of the Council in configurations other than that of foreign affairs (Articles 16(9) new TEU and 236 TFEU) and the President of the Commission. Future practice will have to show how the new arrangements will work out. This being said, one may sincerely wonder whether the new arrangements will really contribute to enhancing the Union's visibility and to demonstrating greater unity to the outside world. As Kaddous pointed out: "the task of external representation is shared by the High Representative, the President of the European Council and the Commission. Three entities? This comes out to at least three different phone numbers." ${ }^{140}$ As we have seen effective crisis management calls for effective leadership and the new provisions do not entail improvements as to consolidate the different views and opinions of the $27 \mathrm{EU}$ Member States.

The EU's potential in crisis management not only depends on the general institutional set-up, but also and more particularly to the provisions on a Common Security and Defence Policy. The special section in the new TEU devoted to this policy confirms its grown-up status. The Lisbon Treaty not only extends the possibility of the Union in this area (e.g. by extending the so-called Petersberg tasks), but also introduces something of a collective defence obligation, albeit perhaps in statu nascendi. Together with the European Defence Agency (which is already operational) and the possibility of Permanent Structured Cooperation, the new CSDP may allow the Union to further develop its presence as a military actor. The introduction of Permanent Structured Cooperation in the Lisbon Treaty (on the model of the Battlegroup concept) may allow for a more flexible and - the hope is - a more effective development of CFSP/ESDP in the future. The same applies to the so-called 'Group of the willing' clause, on the basis of which the Council may entrust the execution of a task, within the Union framework, to a group of Member States in order to protect the Union's values and serve its interests. The modifications may prevent urgent EU action to be blocked by a small minority of Member States.

140 Kaddous, op.cit., at 219. 
But, taking into account the serious problems many of the crisis management missions were facing (related to weak mandates, unwillingness on the side of Member States to work on capabilities as well as differences of opinion on how to respond), it is questionable whether the institutional innovations will be able to improve things considerably. Indeed, so far available legal competences and possibilities can hardly be blamed for the modest role of the EU in international affairs. And - as the history of CFSP shows - not so much the political will of Member States, but rather the Union's own institutional dynamics will trigger the coming of age of the Union's international capacities. In that sense we have to agree with the observation that the Lisbon Treaty "is also very much an enabling document in the sense that it provides for reforms, but with the details for their operationalization to be determined after the treaty is ratified." ${ }^{\prime 41}$

$141 \quad$ Whitman and Juncos, op.cit., at 45. 